ORNL/CON-479

\title{
MEETING THE CHALLENGE: THE PROSPECT OF ACHIEVING 30 PERCENT ENERGY SAVINGS THROUGH THE WEATHERIZATION ASSISTANCE PROGRAM
}

Martin Schweitzer

Joel F. Eisenberg 


\section{DOCUMENT AVAILABILITY}

Reports produced after January 1, 1996, are generally available free via the U.S. Department of Energy (DOE) Information Bridge.

Web site http://www.osti.gov/bridge

Reports produced before January 1, 1996, may be purchased by members of the public from the following source.

National Technical Information Service

5285 Port Royal Road

Springfield, VA 22161

Telephone 703-605-6000 (1-800-553-6847)

TDD 703-487-4639

Fax 703-605-6900

E-mailinfo@ntis.fedworld.gov

Web site http://www.ntis.gov/support/ordernowabout.htm

Reports are available to DOE employees, DOE contractors, Energy Technology Data Exchange (ETDE) representatives, and International Nuclear Information System (INIS) representatives from the following source.

Office of Scientific and Technical Information

P.O. Box 62

Oak Ridge, TN 37831

Telephone 865-576-8401

Fax 865-576-5728

E-mail reports@adonis.osti.gov

Web site http://www.osti.gov/contact.html

This report was prepared as an account of work sponsored by an agency of the United States Government. Neither the United States Government nor any agency thereof, nor any of their employees, makes any warranty, express or implied, or assumes any legal liability or responsibility for the accuracy, completeness, or usefulness of any information, apparatus, product, or process disclosed, or represents that its use would not infringe privately owned rights. Reference herein to any specific commercial product, process, or service by trade name, trademark, manufacturer, or otherwise, does not necessarily constitute or imply its endorsement, recommendation, or favoring by the United States Government or any agency thereof. The views and opinions of authors expressed herein do not necessarily state or reflect those of the United States Government or any agency thereof. 
ORNL/CON-479

MEETING THE CHALLENGE: THE PROSPECT OF ACHIEVING 30 PERCENT ENERGY SAVINGS THROUGH THE WEATHERIZATION ASSISTANCE PROGRAM

Martin Schweitzer, Joel F. Eisenberg

OAK RIDGE NATIONAL LABORATORY

Date Published: May 2002

Prepared for

U.S. Department of Energy

Office of Building Technology Assistance

Budget Activity Number EC 1701000

Prepared by

OAK RIDGE NATIONAL LABORATORY

Oak Ridge, Tennessee 37831

managed by

UT-BATTELLE, LLC

for the

U.S. DEPARTMENT OF ENERGY

under contract DE-AC05-00OR22725 



\section{TABLE OF CONTENTS}

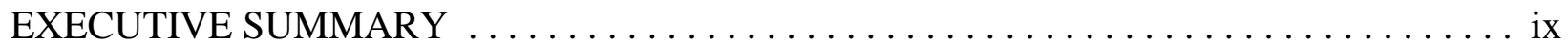

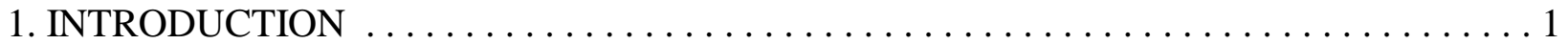

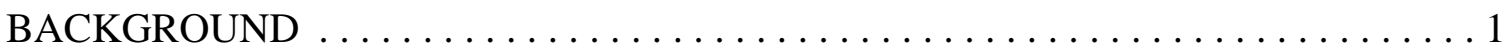

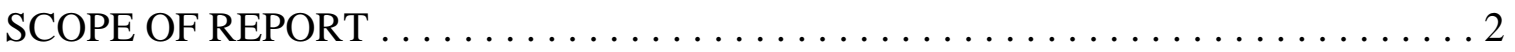

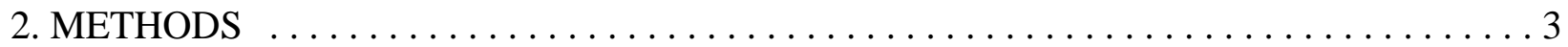

SELECTION OF REPRESENTATIVE CITIES IN ALL CENSUS REGIONS . . . . . 3

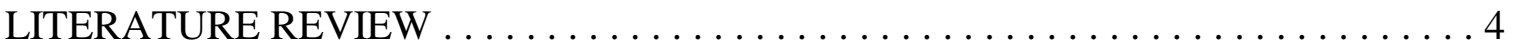

INTERVIEWS WITH WEATHERIZATION STAFF $\ldots \ldots \ldots \ldots \ldots \ldots \ldots \ldots \ldots$

CHOOSING WEATHERIZATION MEASURES $\ldots \ldots \ldots \ldots \ldots \ldots \ldots \ldots \ldots \ldots 6$

PREDICTING SAVINGS WITH THE HOME ENERGY SAVER SYSTEM $\ldots \ldots \ldots \ldots 7$

CALCULATING PERCENTAGE SAVINGS FOR KEY UNITS OF

MEASUREMENT . . . . . . . . . . . . . . . . . . . . . 9

3. DESCRIPTION OF SAMPLE HOUSES $\ldots \ldots \ldots \ldots \ldots \ldots \ldots \ldots \ldots \ldots \ldots \ldots \ldots$

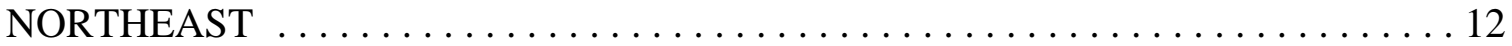

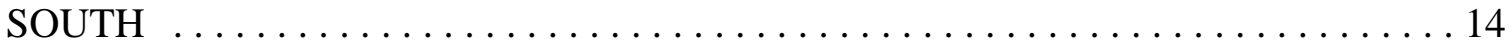

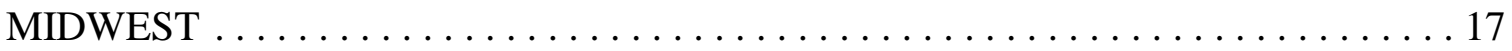

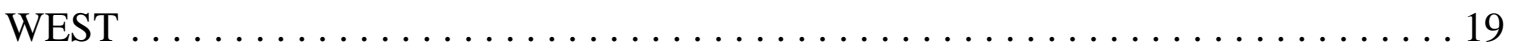

4. PREDICTED EFFECTS OF WEATHERIZATION MEASURES

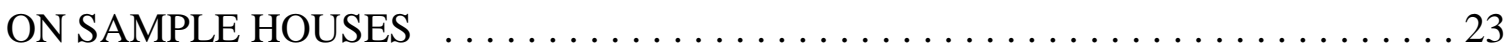

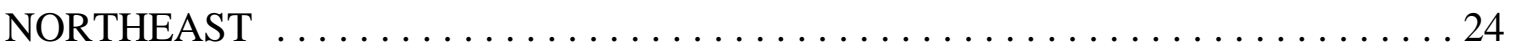

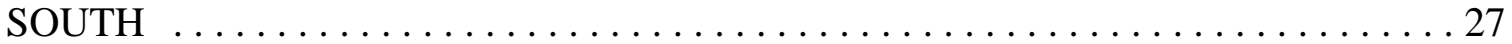

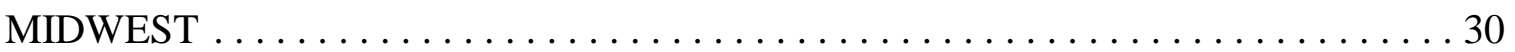

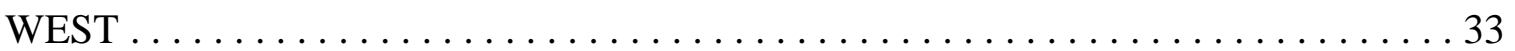

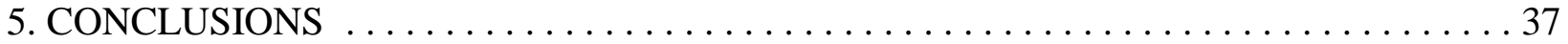

THE PROSPECT OF ACHIEVING 30 PERCENT SAVINGS $\ldots \ldots \ldots \ldots \ldots \ldots . \ldots 38$

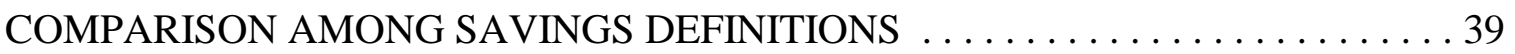

COMPARISON WITHIN REGIONS . . . . . . . . . . . . . . . 41

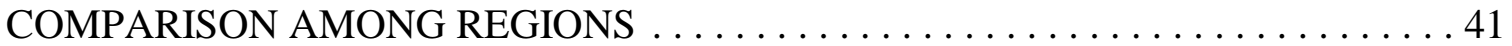

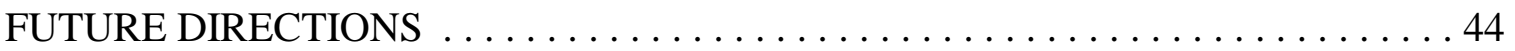

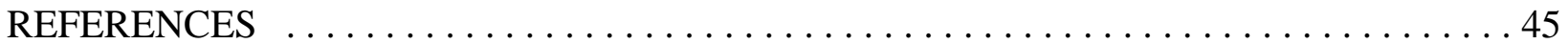





\section{LIST OF FIGURES}

Figure 1. Census regions and representative cities $\ldots \ldots \ldots \ldots \ldots \ldots \ldots \ldots \ldots$

Figure 2. Comparison of key characteristics of typical and high-energy-use houses $\ldots \ldots \ldots 12$

Figure 3. Components of whole-house on-site energy use in Northeast . . . . . . . . . . 14

Figure 4. Components of whole-house on-site energy use in South $\ldots \ldots \ldots \ldots \ldots$

Figure 5. Components of whole-house on-site energy use in Midwest $\ldots \ldots \ldots \ldots \ldots$

Figure 6. Components of whole-house on-site energy use in West $\ldots \ldots \ldots \ldots \ldots \ldots$

Figure 7. Weatherization measures used in sample houses $\ldots \ldots \ldots \ldots \ldots \ldots \ldots \ldots$

Figure 8. Comparison of savings according to different definitions: $\$ 2500$

package of measures in high-energy-use houses . . . . . . . . . . . . . 39

Figure 9. Pre-Weatherization energy use for heating and hot water as a percent of whole-house on-site energy use: high-energy-use house $\ldots \ldots \ldots \ldots \ldots \ldots 4$ 



\section{LIST OF TABLES}

Table ES. 1. Summary of prospective costs and savings $\ldots \ldots \ldots \ldots \ldots \ldots \ldots \ldots$

Table 1. Example of detailed output provided by home energy saver software $\ldots \ldots \ldots$

Table 2. Key characteristics of typical and high-energy-use houses in Northeast . . . . . . . 13

Table 3. Key characteristics of typical and high-energy-use house in South $\ldots \ldots \ldots \ldots 15$

Table 4. Key characteristics of typical and high-energy-use houses in Midwest $\ldots \ldots \ldots 18$

Table 5. Key characteristics of typical and high-energy-use houses in West ......... 20

Table 6. Weatherization measures, costs, and savings for typical house

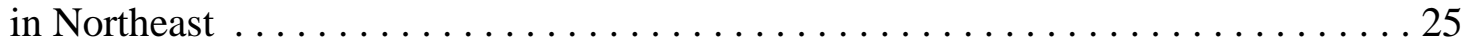

Table 7. Weatherization measures, costs, and savings for high-energy-use

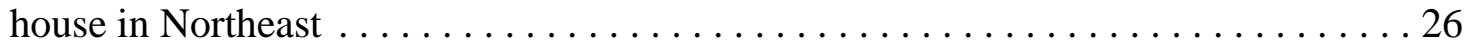

Table 8. Weatherization measures, costs, and savings for typical house in South . . . . . 28

Table 9. Weatherization measures, costs, and savings for high-energy-use house in South . . . . . . . . . . . . . . . . . . . . . . . . . . . 29

Table 10. Weatherization measures, costs, and savings for typical house in Midwest ...... 31

Table 11. Weatherization measures, costs, and savings for high-energy-use

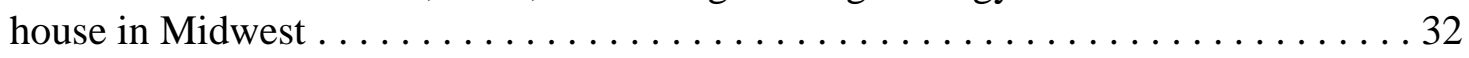

Table 12. Weatherization measures, costs, and savings for typical house in West . . . . . . 34

Table 13. Weatherization measures, costs, and savings for high-energy-use

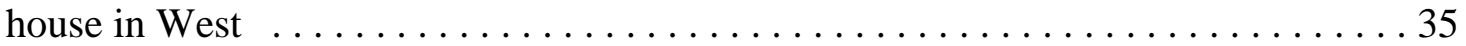

Table 14. Comparison of savings and costs among census regions:

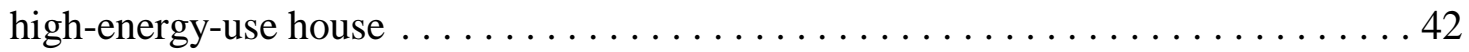





\section{EXECUTIVE SUMMARY}

\section{INTRODUCTION}

The U.S. Department of Energy's (DOE's) Weatherization Assistance Program has been installing energy-efficiency measures in low-income houses for over 25 years, achieving savings exceeding 30 percent of natural gas used for space heating. Recently, as part of its Weatherization Plus initiative, the Weatherization Assistance Program adopted the goal of achieving 30 percent energy savings for all household energy usage. The expansion of the Weatherization Assistance Program to include electric baseload components such as lighting and refrigerators provides additional opportunities for saving energy and meeting this ambitious goal.

This report documents an Oak Ridge National Laboratory study that examined the potential savings that could be achieved by installing various weatherization measures in different types of dwellings throughout the country. Three different definitions of savings are used: (1) reductions in pre-weatherization expenditures; (2) savings in the amount of energy consumed at the house site, regardless of fuel type ("site Btus"); and (3) savings in the total amount of energy consumed at the source ("source Btus"), which reflects the fact that each Btu" of electricity consumed at the household level requires approximately three Btus to produce at the generation source. In addition, the effects of weatherization efforts on carbon dioxide $\left(\mathrm{CO}_{2}\right)$ emissions are examined.

\section{METHODS}

One city was selected from each of the nation's four census regions to represent the broad range of climatic conditions and housing types found in this country. For each region, the number of population-weighted heating degree days was calculated and a city was chosen whose annual heating degree days approximated the regional number. The city selected in the Northeast was Schenectady, New York. The Southern city was Birmingham, Alabama. The city chosen in the Midwest was Moline, Illinois. And the Western city was Eureka, California.

Representatives of state and local agencies with responsibility for implementing the Weatherization Assistance Program in each of the four sample cities were contacted for information on their weatherization efforts. These staff people provided data on a typical home weatherized by their program and a description of their most effective weatherization measures and the associated costs. These were used to define the "typical" homes used in the study.

\footnotetext{
"BTU" stands for "British thermal unit," which is the quantity of heat needed to raise the temperature of one pound of water by one degree Fahrenheit at an existing temperature of 39 degrees Fahrenheit.
} 
A literature review was conducted to provide answers to a number of questions of importance for this study. Past evaluations of low-income weatherization programs were examined to identify key factors associated with high energy savings and they showed that the most consistent predictor of high savings is high pre-weatherization energy consumption. Based on this, we decided to also use a house in each census region with exceptionally high preweatherization energy consumption to represent those dwellings with the greatest potential to achieve high savings. We then reviewed a number of other studies for a description of the key characteristics of those houses in the top 25 percent of their study group in terms of energy consumption. The available information indicated that such dwellings have, among other things, 25 percent more conditioned floor area and 35 percent more air infiltration than the typical house, only 75 percent of the attic insulation and 15 percent of the wall insulation of a typical dwelling, and less efficient furnaces, water heaters, and refrigerators than are typically found. Dwellings with these characteristics are referred to in this study as "high-energy-use houses." Additional documents were reviewed for information on available energy-efficiency measures and their performance.

Savings were calculated for a set of weatherization measures costing roughly $\$ 2500$ and, where additional cost-effective measures were available, for an expanded package of measures as well. The total costs of the weatherization packages include overhead costs. Only those measures with a savings-to-investment ratio of 1.0 or greater were used in this study. In general, those measures with the greatest on-site energy savings were selected first.

The magnitude of savings associated with the installation of each cost-effective weatherization measure in typical and high-energy-use houses in each of the four climaticallydiverse cities was predicted using Home Energy Saver, an Internet-based system developed by Lawrence Berkeley National Laboratory for DOE and the U.S. Environmental Protection Agency. This system, which is driven by the DOE-2 building simulation program (version 2.1E), can be used to measure the effects of making various energy-efficiency improvements to any given residence. One major reason that Home Energy Saver was employed in this study was its ability to calculate whole-house energy use and savings.

The savings shown for each house by Home Energy Saver were multiplied by an adjustment factor of 0.60 to reflect the fact that actual savings from residential weatherization programs tend to be substantially less than the engineering estimates indicate. These adjusted savings were added to the savings for several baseload-reduction measures that were provided by the literature review to get total whole-house savings. From these, we calculated percentage savings for the four units of measurement used in this study: energy bills, site Btus, source Btus, and $\mathrm{CO}_{2}$ emissions.

\section{KEY FINDINGS}

Table ES. 1 summarizes the costs and savings associated with installing a $\$ 2500$ set of weatherization measures and an expanded weatherization package in typical and high-energy-use 
Table ES. 1. Summary of prospective costs and savings

\begin{tabular}{|c|c|c|c|c|c|c|c|c|}
\hline & \multicolumn{2}{|c|}{ Northeast } & \multicolumn{2}{|c|}{ South } & \multicolumn{2}{|c|}{ Midwest } & \multicolumn{2}{|c|}{ West } \\
\hline & Typical & $\begin{array}{c}\text { High- } \\
\text { Energy-Use }\end{array}$ & Typical & $\begin{array}{l}\text { High-Energy- } \\
\text { Use }\end{array}$ & Typical & $\begin{array}{l}\text { High-Energy- } \\
\text { Use }\end{array}$ & Typical & $\begin{array}{c}\text { High- } \\
\text { Energy-Use }\end{array}$ \\
\hline \multicolumn{9}{|l|}{$\$ 2500$ Package } \\
\hline Weatherization costs & $\$ 2,581$ & $\$ 2,732$ & $\$ 2,370$ & $\$ 2,725$ & $\$ 2,388$ & $\$ 2,638$ & $\$ 1,499$ & $\$ 2,311$ \\
\hline Energy bill savings & $15.5 \%$ & $18.7 \%$ & $15.2 \%$ & $15.9 \%$ & $20.4 \%$ & $22.7 \%$ & $14.3 \%$ & $20.6 \%$ \\
\hline Site Btu savings & $21.8 \%$ & $24.6 \%$ & $15.2 \%$ & $15.9 \%$ & $25.0 \%$ & $26.6 \%$ & $16.9 \%$ & $24.5 \%$ \\
\hline Source Btu savings & $17.1 \%$ & $20.3 \%$ & $15.2 \%$ & $15.9 \%$ & $21.5 \%$ & $23.7 \%$ & $14.8 \%$ & $21.5 \%$ \\
\hline $\mathrm{CO}_{2}$ reductions & $17.6 \%$ & $20.9 \%$ & $15.2 \%$ & $15.9 \%$ & $20.1 \%$ & $22.5 \%$ & $16.6 \%$ & $24.1 \%$ \\
\hline \multicolumn{9}{|l|}{ Expanded Package } \\
\hline Weatherization costs & $\$ 3,439$ & $\$ 5,603$ & N/A & $\$ 3,500$ & $\$ 3,200$ & $\$ 7,175$ & N/A & N/A \\
\hline Energy bill savings & $19.0 \%$ & $29.7 \%$ & N/A & $20.5 \%$ & $23.2 \%$ & $33.9 \%$ & N/A & N/A \\
\hline Site Btu savings & $23.2 \%$ & $34.4 \%$ & N/A & $20.6 \%$ & $25.9 \%$ & $37.2 \%$ & N/A & N/A \\
\hline Source Btu savings & $20.0 \%$ & $30.0 \%$ & N/A & $20.6 \%$ & $23.8 \%$ & $34.7 \%$ & N/A & N/A \\
\hline $\mathrm{CO}_{2}$ reductions & $20.3 \%$ & $31.4 \%$ & N/A & $20.6 \%$ & $23.1 \%$ & $33.7 \%$ & N/A & N/A \\
\hline
\end{tabular}

houses in each of the four cities examined in this study. For all the cities studied and all the units of measurement used, greater savings are always found in houses with high pre-weatherization energy consumption than in typical dwellings. Also, for a given house in a particular city, higher savings can be realized through installation of an expanded set of weatherization measures than from a $\$ 2500$ package in those cases where additional measures are cost-effective.

Weatherization measures resulting in relatively high savings for most of the houses studied are air sealing, installing attic and wall insulation, replacing an old refrigerator with a high-efficiency unit, resetting the temperature on an existing water heater, and installing a programmable thermostat on the central heating system. Refrigerator replacement, which is a baseload measure that reduces electricity consumption, excels in terms of fuel bill savings, $\mathrm{CO}_{2}$ reductions, and cutting the use of source Btus. The other measures, in contrast, tend to do best at reducing on-site energy consumption. Measures aimed at reducing heat loss through the building envelope (i.e., air sealing and insulation) continue to achieve the highest levels of savings in cold climates, while baseload reduction measures (including water heater measures) have a proportionally greater effect in milder areas where the heating load is substantially lower. The application of new technologies and weatherization techniques, such as heat pump water heaters and advanced duct sealing, might improve the potential for higher savings in typical as well as 
high-energy-use houses, but an exploration of the possible impact of such changes is beyond the scope of this study.

The savings projected and displayed in Table ES-1 should not be construed to be strictly regional in character. For example, one should not conclude that energy savings of more than 30 percent are only possible in the Northeast and Midwest or that savings of 20 percent are the maximum achievable in the South. Rather, the characteristics of the housing stock, family size, and appliance efficiency taken in conjunction with heating and cooling loads will determine the potential for cost effective savings. Other important findings from this study are as follows:

- High-energy-use houses in the colder climate regions have the potential for costeffective site Btu savings of more than 30 percent.

- The total investment (including program overhead) required to achieve savings of this magnitude ranges from approximately $\$ 5,600$ to $\$ 7,175$, depending on the housing stock and measures taken.

- High-energy-use houses in some warmer regions can achieve savings of site Btus in the 25 percent range when there is a high level of hot water usage and an inefficient water heater and refrigerator present.

- Baseload electric measures can make a major contribution to improved energy savings for weatherization in areas with modest heating loads. Cost-effective savings of approximately 16 to 25 percent are possible in high-energy-use housing in these areas with investments of roughly $\$ 2,500$.

- Cost-effective savings of 30 percent or more are not likely to occur in the typical lowincome house in any region even with a higher level of investment than $\$ 2,500$. Achieving these savings levels with commonly used efficiency measures therefore depends on careful selection of houses with high-energy-use characteristics where higher levels of investment are cost-effective.

- As shown in previous studies, savings follow consumption. At each of the four sites analyzed, regardless of the unit of measurement used (i.e. fuel bill savings, site Btu savings, source Btu savings, or $\mathrm{CO}_{2}$ reductions), the high-energy-use house realizes higher percentage savings than does the typical dwelling, given comparable levels of investment.

- Annual savings of between $\$ 900$ and $\$ 1,000$ can be achieved on low-income energy bills in high-energy-use households in colder climates. Annual savings of approximately $\$ 370$ to $\$ 410$ are estimated for high-energy-use houses in the warmer climate regions. 


\section{INTRODUCTION}

This report explores the feasibility of achieving whole-house savings ${ }^{1}$ in the 30 percent range in existing housing units through the U.S. Department of Energy's (DOE's) Weatherization Assistance Program. The report documents an Oak Ridge National Laboratory (ORNL) study that examined the potential savings that could be realized by making various energy-efficiency improvements in different types of dwellings throughout the country and identified the costs associated with those weatherization measures.

\section{BACKGROUND}

The Weatherization Assistance Program was created by Congress in 1976 to help increase residential energy efficiency in low-income households, thereby lowering energy bills and improving health and safety for this segment of the population. The Weatherization Assistance Program is administered by DOE and is implemented by the state through local agencies in all 50 states and the District of Columbia. Since its inception, it has weatherized approximately five million homes throughout the country. Recent studies have shown that the Weatherization Program has been able to achieve savings of over 30 percent of natural gas used for home heating. Natural gas is the predominant heating fuel used by low-income households.

Recently, the Weatherization Program expanded its scope to include electric baseload components such as water heaters and refrigerators. This expansion beyond the traditional emphasis on the building envelope and home heating system is part of the Weatherization Plus initiative, the planned evolution of the program to a whole-house, whole-community focus. The whole-house approach provides additional potential for energy savings because it creates the opportunity to install efficiency measures in "plug" loads such as refrigerators and other appliances. The Weatherization Plus initiative adopted the ambitious long term goal of achieving 30 percent energy savings, not just in space heating energy use, but for all residential usage by low-income households including water heating, space cooling, and appliances.

DOE's Office of Building Technology Assistance asked ORNL to explore the prospect of achieving 30 percent whole-house energy savings in the houses served by the Weatherization Assistance Program.

While the concept of reducing whole-house energy use by 30 percent may sound simple, there are actually three different ways in which these savings can be defined. According to the

\footnotetext{
${ }^{1}$ Whole-house savings refers to the magnitude of savings relative to all household energy consumption, regardless of fuel type. In contrast to typical Weatherization Program evaluations of the past, which have focused on savings for the primary heating fuel, the whole-house approach looks at the consumption of all fuels, converting them into common units (generally Btus or dollars) so that they can be summed.
} 
first definition, "30 percent savings" means a savings of 30 percent of pre-weatherization expenditures for all household fuels. The second approach converts all on-site energy consumption, regardless of energy type, to Btus and defines "30 percent savings" as 30 percent of the number of Btus consumed in the house during the pre-weatherization period ("site Btus"). The third definition sees "30 percent savings" as 30 percent of the pre-weatherization Btus consumed at the energy source ("source Btus"). According to this last definition, each Btu of electricity consumed at the household level represents approximately three Btus of energy at the source because of the substantial losses that occur during electricity generation and transmission. As will be seen in subsequent chapters of this report, the magnitude of savings can vary significantly depending on which of the above definitions is used. In past studies of the Weatherization Assistance Program, energy savings have typically been reported as the reduction in on-site consumption.

\section{SCOPE OF REPORT}

Subsequent chapters of this report discuss the research methods employed in the ORNL study and the major findings of that effort. Chapter 2 provides a detailed description of the research methods used, focusing on the selection of representative cities in each census region, the literature review that was performed, the interviews that were conducted with weatherization staff in the sample cities and states, and the calculation of energy savings associated with various weatherization measures. In Chapter 3, the sample houses studied in each census region are described. These include a house that is considered typical of low-income residences in the region as well as a house that is characterized by higher-than-average pre-weatherization energy consumption $^{2}$. Chapter 4 discusses the effects of various weatherization measures on the sample houses in terms of four units of measurement: fuel bills, site Btus, source Btus, and carbon dioxide $\left(\mathrm{CO}_{2}\right)$ emissions. The predicted effects from a $\$ 2500$ package of measures are described as are the effects of an expanded package designed to maximize household savings. In Chapter 5 , the conclusions of the study are presented. These include a comparison of the savings that can be achieved in different types of houses and at different levels of investment within a given city as well as the differences in savings observed among the various census regions. The manner in which magnitude of savings varies based on the units of measurement used is also discussed. Finally, we identify the circumstances under which whole-house savings in the 30 percent range are achievable.

\footnotetext{
2 As discussed in Chapter 2, many past evaluations have shown that houses with high pre-weatherization energy use tend to achieve very substantial savings in response to being weatherized. Accordingly, high-energy-use houses were identified and studied because of their potential for realizing exceptionally high savings.
} 


\section{METHODS}

The conceptual design of this study was simple: identify a small set of houses to represent the different kinds of low-income residences served by the Weatherization Assistance Program around the country and examine the costs and savings associated with installing various weatherization measures in those dwellings. The major steps by which this study was implemented are discussed below.

\section{SELECTION OF REPRESENTATIVE CITIES IN ALL CENSUS REGIONS}

The first major task in the ORNL study was to identify a limited number of cities to represent the broad range of climatic conditions and housing types found in this country. The twin objectives were to represent the diversity of conditions faced by the Weatherization Program and to portray conditions that also would be frequently found in the Weatherization housing stock. We decided to choose one city from each of the nation's four census regions: the Northeast, the South, the Midwest, and the West. Average population-weighted heating degree days were calculated for each census region and a city was chosen whose average heating degree days $^{3}$ (Rutkowski 1986) approximated the population-weighted number. In addition to climate, other factors considered in the selection process were the city's location within its region, the prevailing fuel mix, and the availability of needed information.

Population-weighting is accomplished by multiplying the average heating degree days for each state (Heim, Garvin, and Nicodemus 1993) by its population (U.S. Bureau of the Census 1999). The resulting numbers are summed for all the states in a given region and that number is divided by the region's total population to yield population-weighted heating degree days. The population-weighting process ensures that the regional average will reflect the conditions where most people actually live. In the Western region, for example, the population-weighted average number of heating degree days is much closer to the number for California, where over half of the region's population resides, than to the numbers for the many colder, but more sparsely populated, states (e.g., Montana, Wyoming, Colorado, Idaho) that also are part of the region.

Figure 1 shows the states that make up each census region as well as the four cities that were chosen to be the focus of this study. In the Northeast, Schenectady, New York was selected. In the South, the representative city is Birmingham, Alabama. The Midwestern city is Moline, Illinois, and the West is represented by Eureka, California. Everywhere but in the West, the chosen city is centrally situated within its region. And the selected cities are all located in the

\footnotetext{
${ }^{3}$ Heating degree days are calculated for a city or state by taking the mean temperature for each day in a given year and subtracting it from 65. All of the non-negative values are summed to get the annual number of heating degree days. Typically, a 30 year average of annual heating degree days is used to represent typical climatic conditions for any given city or state.
} 


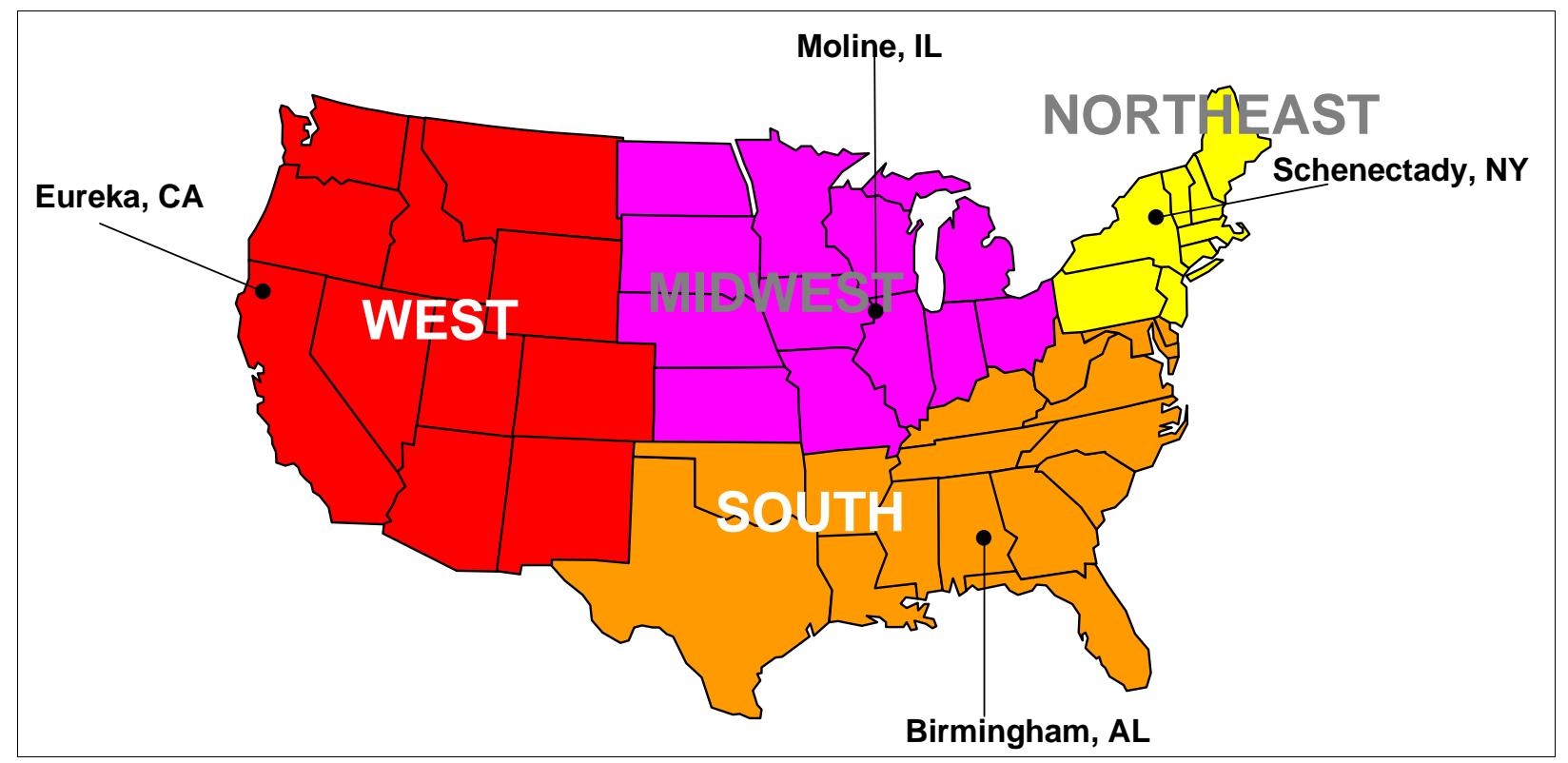

Figure 1. Census regions and representative cities

most populous state of their region except in the South. The four cities represent a great variety in terms of climate and, as shown in Chapter 3, housing characteristics. While four cities cannot paint a definitive picture of the entire country, an examination of low-income dwellings in those locations does suggest the kinds of savings that can be achieved nationwide, the types of variation that can be expected from place to place, and the circumstances under which wholehouse savings in the 30 percent range are achievable.

\section{LITERATURE REVIEW}

A literature review was conducted to provide answers to a number of questions of importance for this study. First, past evaluations of low-income weatherization programs were examined to identify key factors associated with the achievement of especially high energy savings (Brown et. al. 1993; Berry 1997; Schweitzer and Berry 1999; Schweitzer and Berry 2000) ${ }^{4}$. Most of the studies looked at weatherization efforts in a large number of states, and they showed that the most consistent predictor of high savings is a high level of pre-weatherization energy consumption. Therefore, we decided to use a high-energy-use house in each census region to represent those dwellings with the greatest potential to achieve high savings through the Weatherization Program, as well as a more typical house.

${ }^{4}$ Knowing the characteristics of high-saving houses is considered important so that homes with the appropriate characteristics could be targeted in future efforts designed to achieve whole-house savings in the 30 percent range. 
A number of Weatherization Program evaluations were then reviewed (Blasnik 1998; RLW Analytics 1998; Reed et. al. 1997; Schweitzer and Berry 2000; Berry and Brown 1994) to see what they reveal about the key characteristics of houses in the upper 25 percent of their study group in terms of pre-weatherization energy use. These studies, together with a review of primary data from a recent evaluation of the Weatherization Program in Washington State, revealed a number of systematic differences between houses with typical energy usage and those in the top quartile of energy-consuming houses. The high consuming houses were found to have higher levels of air infiltration, less attic and wall insulation, and greater floor area. These houses also had slightly less efficient furnaces (Ternes et. al. 1991) than the typical dwelling. Other sources provided information on the characteristics of the older water heaters (GAMA 1990) and refrigerators (Wenzel et. al. 1997) that are less energy efficient and, therefore, were included as part of the high consuming houses. These houses are referred to in this report as "high-energyuse houses." A detailed description of the differences between typical and high-energy-use houses in terms of all the characteristics mentioned above is provide in Chapter 3.

Information on available energy-efficiency measures and their performance came from a variety of sources. A description of the measures traditionally used in the Weatherization Program was provided by the national evaluation prepared by ORNL in 1993 (Brown et. al., 1993), while information on newer approaches to reducing baseload electricity use and on current appliance efficiencies came from a number of recent studies (Martin and Gettings 1998; Nadel et. al. 1998; Wenzel et. al. 1997; U.S. Energy Information Administration 1995).

Finally, recognizing that predicted energy savings using audit estimates tend to be higher than actual realized savings from weatherization, it was necessary to develop an adjustment factor to take this phenomenon into account. Empirical data comparing estimated energy savings to the actual savings achieved by weatherization efforts came from several different reports (Brown and Mihlmester 1995; Nadel and Keating 1991; Gettings et. al. 1998). The documents reviewed suggest that an adjustment factor of 0.60 is appropriate to use for residential direct assistance programs, because actual savings typically amount to about 60 percent of the predicted reduction in energy usage.

\section{INTERVIEWS WITH WEATHERIZATION STAFF}

In order to make the analysis as realistic as possible it was important to gather information on actual housing stock, typical weatherization measures and the cost of these measures. State and local staff people with responsibility for implementing the Weatherization Assistance Program in each of the four cities examined in this study ${ }^{5}$ were contacted by telephone and asked to provide information regarding their weatherization efforts. In all cases, a staff member in the state office was interviewed, and in three of the four cases this person

\footnotetext{
${ }^{5}$ State and local contacts in the four cities were provided to ORNL by the director of the Weatherization Assistance Program Technical Assistance Center in Washington, DC.
} 
referred us to at least one local weatherization staff member for more detailed information. In most cases, a brief initial interview was conducted and then a list of the information needed on a typical weatherized home was faxed to the contact person along with another list asking for a description of the most effective weatherization measures commonly installed in the houses served and the costs of those measures.

The list of data requested for the typical house in each city contained almost 30 items, such as the year built, size of conditioned floor area, fuels used for heating and hot water, current fuel prices, and window type. The respondents completed the sheets and faxed them back to ORNL and then a follow-up interview was conducted to provide any necessary clarification of the information provided.

The descriptive information provided by weatherization staff was used to characterize the typical house in each city, with one notable exception. In the case of the representative city in the South, the respondent reported that the typical weatherized house was heated with gas and used this same fuel for domestic hot water. Because electric heat and hot water are more common in the South than are gas heat and hot water (U.S. Energy Information Administration 1999), we made the Southern house all-electric to reflect dominant conditions in the region. Interviews with weatherization staff in a number of different cities and states throughout the South indicated that electric baseboard heaters are more common than heat pumps or central electric furnaces in low-income houses in this region, so that was the type of heating system that we assigned to the typical house in the South. All other characteristics of the low-income house provided by the weatherization staffer for our Southern city were accepted without change.

\section{CHOOSING WEATHERIZATION MEASURES}

As noted earlier, the appropriate weatherization measures to install in the sample houses were suggested by the state and local weatherization staff interviewed and the literature review. For each house, the cost-effectiveness of the various potential measures was tested using the fuel bill savings generated by the Home Energy Saver system, the savings adjustment factor suggested by the literature review, and the site-specific installation costs provided by the weatherization staff responsible for program implementation. Savings-to-Investment Ratios (SIRs) were calculated for each measure, using the DISCOUNT software developed by the National Institute of Standards and Technology (Peterson 1993) ${ }^{6}$ to compute the present value of adjusted savings and dividing that by the cost of the measure. All measures that were found to be cost-effective for a given house (i.e., that had a SIR of 1.0 or greater) went into the package of weatherization

\footnotetext{
${ }^{6}$ The DISCOUNT software computes the present value of energy savings for each weatherization measure, based on the dollar vale of the adjusted annual energy savings, geographic region, rate type (i.e., residential), energy type (i.e., gas or electricity), year of installation, measure lifetime (in years), discount rate, and energy price escalation rate (derived from U.S. Energy Information Administration price projections). For each measure, we assumed the same lifetime and used the same discount rate commonly used by the Weatherization Assistance Program.
} 
measures for that dwelling. Overhead $\operatorname{costs}^{7}$ were added to each complete package of measures and SIRs were recalculated to ensure that the entire package of measures was cost effective. If the total cost of the available set of cost-effective measures (including overhead) substantially exceeded $\$ 2500$, those measures providing the greatest on-site energy savings went into a \$2500 package while the measures with lower levels of savings were made part of an expanded package $^{8}$. The only exceptions to this rule were where a combination of inexpensive measures would result in higher on-site energy savings at a lower cost than a single expensive measure or where a measure was so expensive that it would not fit under the $\$ 2500$ ceiling even if it did replace several inexpensive measures.

\section{PREDICTING SAVINGS WITH THE HOME ENERGY SAVER SYSTEM}

The magnitude of savings associated with the installation of various weatherization measures in typical and high-energy-use houses in each of the four representative cities was predicted using the Home Energy Saver system, developed by Lawrence Berkeley National Laboratory for DOE and the U.S. Environmental Protection Agency. Home Energy Saver is an Internet-based system that allows a user to go online, describe the major characteristics of a given house in a specific geographic location, and measure the effects of making various energyefficiency improvements to the residence. As shown in Table 1, the system provides detailed information on energy consumption, fuel bills, and $\mathrm{CO}_{2}$ emissions for the whole house and for six key components: heating, cooling, hot water, major appliances, lighting, and miscellaneous functions. Home Energy Saver is driven by the DOE-2 building simulation program (version 2.1E), which performs hourly calculations to compute energy use for a typical weather year (Lawrence Berkeley National Laboratory 1999). DOE-2 is a highly complex and reputable model that accounts for the interactions between the structure of the house, its interior conditions, and outside temperatures.

The Home Energy Saver system was used to calculate savings in this study for several reasons. As mentioned above, the DOE-2 model lies at the heart of the system and it has a reputation for producing highly accurate results. Perhaps the greatest strength of Home Energy Saver for the purposes of this study is that it calculates whole-house energy use and savings, examining baseload consumption in addition to determining the energy consumed for heating, cooling, and hot water. Also, the Home Energy Saver system allows the pre-weatherization characteristics of any given house to be described in great detail and supplies empirically-based default values in the event that complete information is not available on every feature of the

${ }^{7}$ Overhead costs were calculated in the same way they typically are for each city studied. In three cases, a percentage of labor and material costs was used. In the fourth case, program overhead was assessed as a flat fee.

${ }^{8}$ The actual cost of the "\$2500 package" (including overhead costs) varied from a low of $\$ 1444$ in one typical house where there were relatively few cost-effective weatherization measures available to a high of $\$ 2732$ in one high-energy-use house located in a cold climate. 
Table 1. Example of detailed output provided by Home Energy Saver software

Annual Projection

\begin{tabular}{|c|c|c|}
\hline \multicolumn{3}{|c|}{ Birmingham, Alabama } \\
\hline \multirow{3}{*}{ Whole House } & Expenditures & $\$ 1,200$ \\
\hline & Energy & $19,037 \mathrm{kWh}$ \\
\hline & Pollution & $32,115 \mathrm{lb} . \mathrm{CO}_{2}$ \\
\hline \multirow{3}{*}{ Heating } & Expenditures & $\$ 129$ \\
\hline & Energy & 2,043 kWh \\
\hline & Pollution & 3,444 lb. $\mathrm{CO}_{2}$ \\
\hline \multirow{3}{*}{ Cooling } & Expenditures & $\$ 116$ \\
\hline & Energy & $1,840 \mathrm{kWh}$ \\
\hline & Pollution & $3,101 \mathrm{lb} . \mathrm{CO}_{2}$ \\
\hline \multirow{3}{*}{ Hot Water } & Expenditures & $\$ 227$ \\
\hline & Energy & $3,601 \mathrm{kWh}$ \\
\hline & Pollution & 6,070 lb. $\mathrm{CO}_{2}$ \\
\hline \multirow{3}{*}{ Major Appliances } & Expenditures & $\$ 357$ \\
\hline & Energy & $5,662 \mathrm{kWh}$ \\
\hline & Pollution & 9,569 lb. $\mathrm{CO}_{2}$ \\
\hline \multirow{3}{*}{ Lighting } & Expenditures & $\$ 74$ \\
\hline & Energy & $1,172 \mathrm{kWh}$ \\
\hline & Pollution & 1,976 lb. $\mathrm{CO}_{2}$ \\
\hline \multirow{3}{*}{ Miscellaneous } & Expenditures & $\$ 297$ \\
\hline & Energy & $4,719 \mathrm{kWh}$ \\
\hline & Pollution & $7,955 \mathrm{lb} . \mathrm{CO}_{2}$ \\
\hline
\end{tabular}


house in question ${ }^{9}$. Finally, Home Energy Saver allows nearly all possible weatherization measures to be entered incrementally and predicts the effects of each one ${ }^{10}$.

\section{CALCULATING PERCENTAGE SAVINGS FOR KEY UNITS OF MEASUREMENT}

Separate spread sheets were created for each of the houses studied (i.e., the typical and high-energy-use house in each of the four cities). For each house, the pre-weatherization fuel bill (in dollars), electric use (in $\mathrm{kWh}$ ), gas use (in therms), and $\mathrm{CO}_{2}$ emissions (in pounds) - as provided by Home Energy Saver-were entered into the spreadsheet. For the high-energy-use house, the pre-weatherization values for the above-named variables were adjusted upward to reflect the fact that the pre-weatherization dwelling has greater air infiltration, and therefore greater energy use and associated fuel costs and emissions, than indicated by the Home Energy Saver model ${ }^{11}$. Then, data were entered into the spreadsheets describing the fuel bill, electric and gas use, and $\mathrm{CO}_{2}$ emissions for each house following the installation of each weatherization measure. The spreadsheet automatically calculated the energy and fuel bill savings and $\mathrm{CO}_{2}$ reductions for each measure and expressed the energy savings as total site and source Btus for all fuels combined. These energy savings numbers, along with the fuel bill savings and $\mathrm{CO}_{2}$ reductions, were multiplied by the adjustment factor described earlier (0.60) to account for the fact that actual savings from residential weatherization programs tend to be substantially less than the engineering estimates.

For a few measures (i.e., low-flow showerhead, high-efficiency refrigerator, compact fluorescent bulbs), the magnitude of savings was provided by several recent reports (Martin and Gettings 1998; Nadel et. al. 1998; Wenzel et. al. 1997; U.S. Energy Information Administration 1995), and these savings numbers were put into the spreadsheets along with the numbers generated by Home Energy Saver. Once all the data were entered, the spreadsheets summed the savings from the various measures installed in each house and calculated percentage savings for four key units of measurement: fuel bills, site Btus, source Btus, and $\mathrm{CO}_{2}$ emissions. These savings were calculated for both a $\$ 2500$ package of weatherization measures as well as for an expanded weatherization package.

${ }^{9}$ For example, Home Energy Saver provides default values for house shape, numbers of windows and doors, types of appliances and amount of usage, energy factor and recovery efficiency of water heater, and number of light fixtures.

${ }^{10}$ Home Energy Saver does not directly calculate the effects of water heater wrap or furnace clean and tune, but it does allow the user to change the water heater energy factor and furnace efficiency to reflect the changes resulting from those measures. Accordingly, ORNL staff calculated those changes using accepted computational methods and entered the appropriate energy factor and furnace efficiency numbers as inputs for Home Energy Saver.

11 The Home Energy Saver model assumes standard infiltration rates in the houses studied, but the literature review suggested that air filtration in the high-energy-use house is 35 percent greater (in terms of cubic feet per minute or CFM) than in the typical house. ORNL staff calculated additional energy consumption for the high-energyuse house by using energy use data provided by Home Energy Saver and the building leakage values underlying those calculations to model how energy use varies with changes in air infiltration rates. The equation generated by that process was used to calculate energy use for the high-energy-use house, which has 35 percent more CFM than the typical dwelling. 



\section{DESCRIPTION OF SAMPLE HOUSES}

This chapter presents descriptions of typical and high-energy-use houses for a city in each census region. As noted in the previous chapter, the cities chosen to represent the census regions were: Schenectady, New York for the Northeast; Birmingham, Alabama, for the South; Moline, Illinois, for the Midwest; and Eureka, California for the West. The amount of energy used in each house for various functions (e.g., heating, hot water, lighting) was calculated by the Home Energy Saver system (described in Chapter 2). Key characteristics of a typical low-income house were provided by local or state weatherization staff responsible for implementing the Weatherization Assistance Program in each city. Obviously, all houses in a given area are not identical, but the typical houses described here have those characteristics that are commonly found in the low-income housing stock in the four cities that were studied ${ }^{12}$.

The characteristics of the high-energy-use houses were developed by starting with the typical house models and making adjustments derived from the literature review described in Chapter 2 which reflect differences in the characteristics between typical houses and those in the upper quartile in terms of energy consumption. Specifically, floor area was increased by 25 percent, air infiltration was increased by 35 percent, and the amount of insulation was reduced to approximately 75 percent of the attic insulation and 15 percent of the wall insulation found in the typical house ${ }^{13}$. In addition, the efficiency of gas furnaces was lowered by 1 percent, the water heater temperature was set to medium-high (the highest setting commonly seen in the field), and the energy factor ${ }^{14}$ for the water heater was reduced by .04 for gas units and .06 where the fuel was electricity. The annual consumption rate for the refrigerator was raised from 1155 to $1500 \mathrm{kWh}$ per year to represent an older, less-efficient unit and the high-energy-use house was given no moveable window shades instead of the venetian blinds or drapes found in the typical unit. Finally, the capacities of the window air conditioner and the electric baseboard heaters in the South were made 25 percent greater in the high-energy-use house to reflect the larger area requiring heating and cooling. A quantitative comparison of key characteristics for typical and high-energy-use houses in all regions is provided in Figure 2.

\footnotetext{
12 The only notable exception to this is the heating system described for the typical house in Birmingham, Alabama. Electric baseboard heat was chosen for this house because of its widespread use in low-income houses in the South, despite the fact that it is not characteristic of dwellings in Birmingham. This was done to make the house more representative of the entire region.

${ }^{13}$ Where 75 percent of the typical attic insulation level did not match a commonly-used R-value, the number was rounded down.

${ }^{14}$ The energy factor is equal to the proportion of the fuel's energy that is made available to the user as hot water.
} 


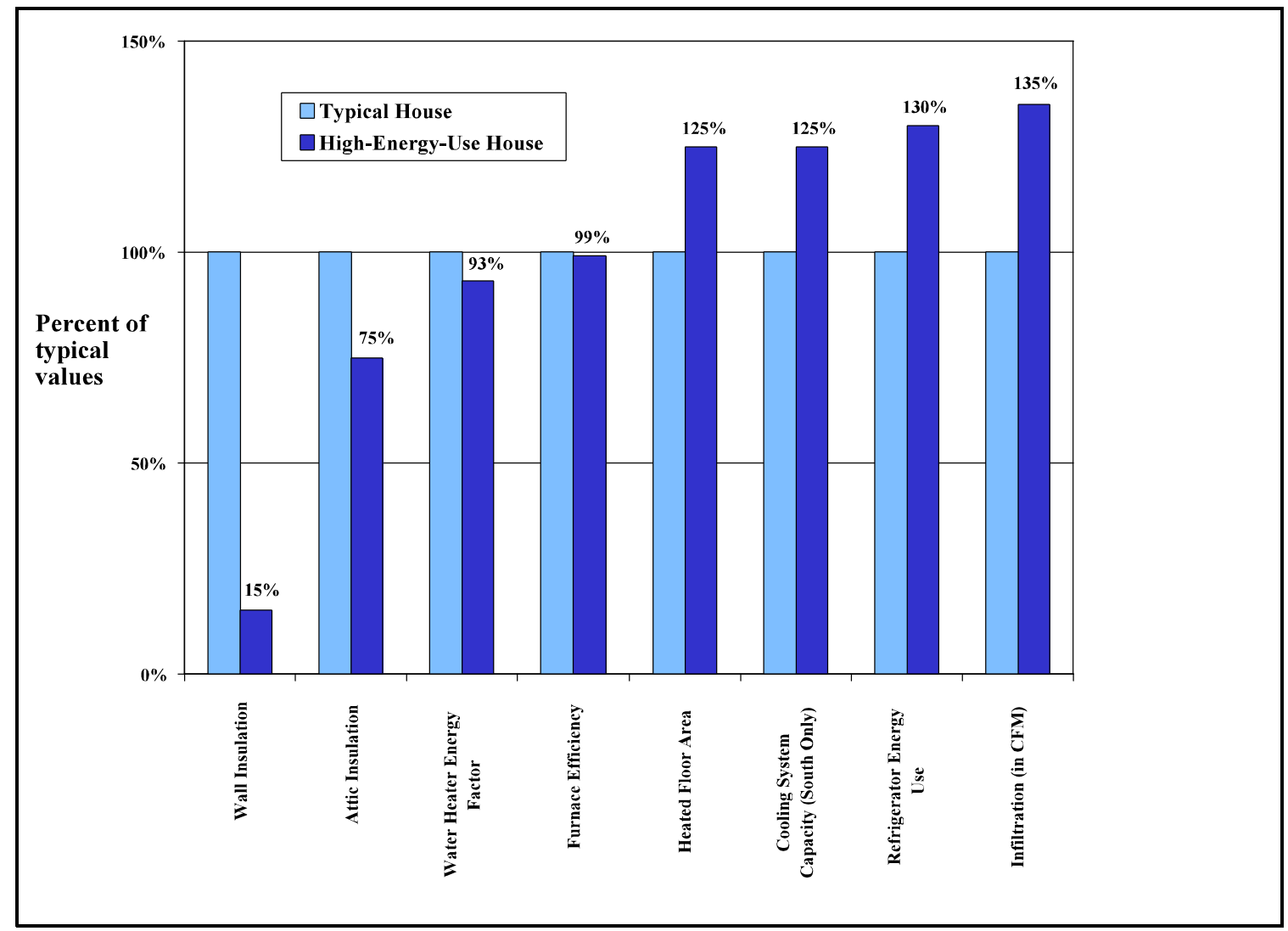

Figure 2. Comparison of key characteristics of typical and high-energy-use houses.

\section{NORTHEAST}

\section{Typical House}

The typical low-income house in Schenectady was built in 1940, has two stories and an unconditioned basement, and contains 1200 square feet of conditioned floor area. Existing attic insulation has a value of R-6, wall insulation is R-7, and there is no floor insulation. This dwelling is heated by a gas boiler and also uses gas as the fuel for its water heater. The water heater has an energy factor of .54 and its temperature is set to medium-high. This city is the coldest of the four studied, averaging 6650 heating degree days per year. Other characteristics of this house are shown in Table 2.

As shown in Figure 3, just over half the whole-house on-site energy consumed in this dwelling is for heating. Hot water accounts for almost one-fourth of whole-house energy consumption, and major appliances use nearly 15 percent of the on-site energy. Other end uses require substantially less energy in this house.

\section{High-Energy-Use House}

The high-energy-use house in the Northeast has many of the same characteristics as the typical low-income house in this region. Key differences, however, are the size of the 
conditioned floor area (1500 square feet), the energy factor of the water heater (.50), and the insulation levels (R-3 in the attic and R-0 in the walls). Also, the air infiltration in the highenergy use house is 35 percent greater (expressed in cubic feet per minute or CFM) than in the typical unit. Other differences between this house and the typical low-income dwelling in this region are shown in Table 2.

Table 2. Key characteristics of typical and high-energy-use houses in Northeast

\begin{tabular}{|c|c|c|c|}
\hline & Characteristics & Typical House & $\begin{array}{c}\text { High-Energy-Use } \\
\text { House }\end{array}$ \\
\hline $\begin{array}{c}\text { General } \\
\text { description }\end{array}$ & $\begin{array}{l}\text { Year built } \\
\text { Number of stories } \\
\text { Conditioned floor area } \\
\text { Type of foundation } \\
\text { Type of exterior siding } \\
\text { Number of windows } \\
\text { Window frame and glazing type } \\
\text { Movable window shades }\end{array}$ & $\begin{array}{l}1940 \\
2 \\
1200 \text { sq. ft. } \\
\text { unconditioned basement } \\
\text { wood } \\
14 \\
\text { wood, double-pane, clear } \\
\text { interior venetian blinds }\end{array}$ & $\begin{array}{l}\text { same } \\
\text { same } \\
1500 \text { sq. ft. } \\
\text { same } \\
\text { same } \\
18 \\
\text { same } \\
\text { none }\end{array}$ \\
\hline $\begin{array}{l}\text { Heating and cooling } \\
\text { systems }\end{array}$ & $\begin{array}{l}\text { Heating fuel and system type } \\
\text { Heating system capacity } \\
\text { Efficiency of heating system } \\
\text { Cooling system type }\end{array}$ & $\begin{array}{l}\text { gas boiler } \\
110,000 \mathrm{Btu} / \mathrm{hr} \\
70 \\
\text { none (except fan) }\end{array}$ & $\begin{array}{l}\text { same } \\
\text { same } \\
69 \\
\text { same }\end{array}$ \\
\hline $\begin{array}{l}\text { Water heater and } \\
\text { refrigerator }\end{array}$ & $\begin{array}{l}\text { Water heater fuel } \\
\text { Capacity (in gal.) } \\
\text { Energy factor (EF) } \\
\text { Water heater temperature setting } \\
\text { Annual energy use by refrigerator }\end{array}$ & $\begin{array}{l}\text { gas } \\
40 \\
.54 \\
\text { medium-high } \\
1155 \mathrm{kWh}\end{array}$ & $\begin{array}{l}\text { same } \\
\text { same } \\
.50 \\
\text { same } \\
1500 \mathrm{kWh}\end{array}$ \\
\hline Existing insulation levels & $\begin{array}{l}\text { Attic insulation } \\
\text { Wall insulation } \\
\text { Floor insulation }\end{array}$ & $\begin{array}{l}\text { R-6 } \\
\text { R-7 } \\
\text { R-0 }\end{array}$ & $\begin{array}{l}\text { R-3 } \\
\text { R-0 } \\
\text { same }\end{array}$ \\
\hline Climate and occupancy & $\begin{array}{l}\text { Heating degree days } \\
\text { Number of occupants, by age: } \\
\qquad \begin{array}{c}0-5 \\
6-13 \\
14-64 \\
\text { over } 64\end{array}\end{array}$ & $\begin{array}{l}0 \\
1 \\
3 \\
1\end{array}$ & $\begin{array}{l}\text { same } \\
\text { same } \\
\text { same } \\
\text { same }\end{array}$ \\
\hline
\end{tabular}




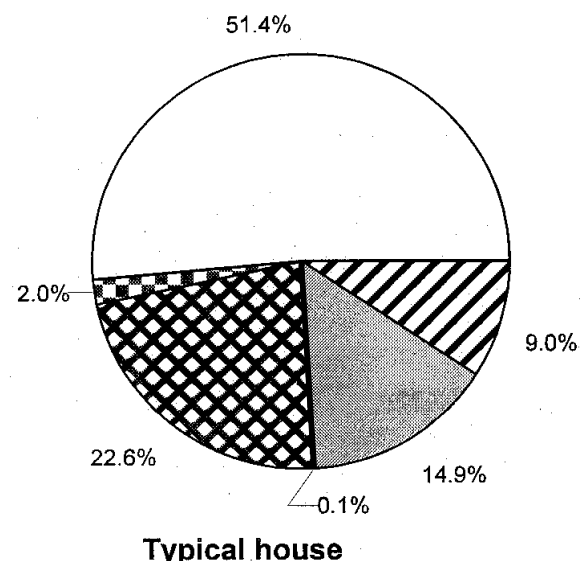

Typical house

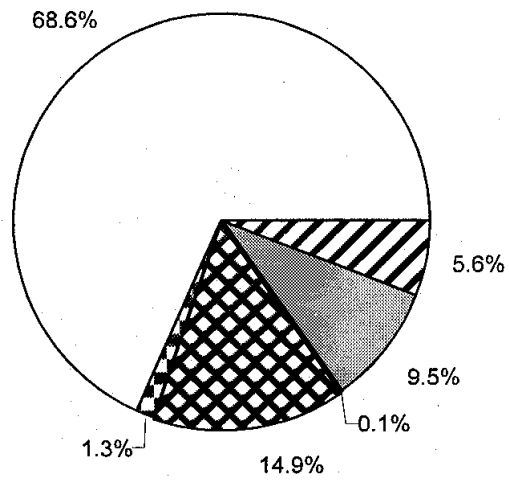

High-energy-use house

$\begin{array}{|llll|}\square . \text { Heating } & \text { lighting } & \text { hot water } \\ \text { cooling } & & \text { major appliances } & \text { miscellaneous } \\ \end{array}$

Figure 3. Components of whole-house on-site energy use in Northeast.

Over two-thirds of the on-site energy used in the high-energy-use house is for heating, which is a substantially greater amount than in the typical house (Figure 3). Conversely, a substantially lower fraction of the total on-site energy is used for hot water, major appliances, and miscellaneous functions. It is important to note that while the percentage of total energy use for water heating and appliances is lower in the high-energy-use house than in the typical house, the actual energy used for those purposes is higher in the former than the latter.

\section{SOUTH}

\section{Typical House}

The typical low-income house in Birmingham, Alabama was built in 1960, has a single story over an unvented crawlspace, and contains 1500 square feet of conditioned floor area. The value of existing insulation is R-9 in the attic and R-7 in the walls. There is no insulation in the floors. This house is heated with electric baseboard units and has room air conditioners that cool approximately 40 percent of the house. The room units have a capacity of 13,000 Btu/per hour, and they are in use 18 hours a day for a four month period. Hot water is provided by an electric water heater with an energy factor of .86 and a temperature setting of medium. This city is the warmest of the four studied, averaging 2710 heating degree days and 1800 cooling degree days per year. Other characteristics of the typical house are shown in Table 3. 
Table 3. Key characteristics of typical and high-energy-use house in South

\begin{tabular}{|c|c|c|c|}
\hline & Characteristics & Typical House & High-Energy-Use House \\
\hline $\begin{array}{c}\text { General } \\
\text { description }\end{array}$ & $\begin{array}{l}\text { Year built } \\
\text { Number of stories } \\
\text { Conditioned floor area } \\
\text { Type of foundation } \\
\text { Type of exterior siding } \\
\text { Number of windows } \\
\text { Window frame and glazing type } \\
\text { Movable window shades }\end{array}$ & $\begin{array}{l}1960 \\
1 \\
1500 \text { sq. ft. } \\
\text { unvented crawlspace } \\
\text { wood } \\
15 \\
\text { wood, single-pane, clear } \\
\text { interior venetian blinds }\end{array}$ & $\begin{array}{l}\text { same } \\
\text { same } \\
1875 \text { sq. ft. } \\
\text { same } \\
\text { same } \\
19 \\
\text { same } \\
\text { none }\end{array}$ \\
\hline $\begin{array}{l}\text { Heating and cooling } \\
\text { systems }\end{array}$ & $\begin{array}{l}\text { Heating fuel and system type } \\
\text { Heating system capacity } \\
\text { Efficiency of heating system } \\
\text { Cooling system type } \\
\text { Cooling system capacity } \\
\text { Efficiency of cooling system } \\
\text { percent of house cooled } \\
\text { Number of hours and months of cooling } \\
\text { system operation }\end{array}$ & $\begin{array}{l}\text { electric baseboard heat } \\
20,000 \mathrm{Btu} / \mathrm{hr} \text {. } \\
98 \\
\text { room AC } \\
13,000 \mathrm{Btu} / \mathrm{hr} . \\
9 \\
40 \text { percent } \\
18 \mathrm{hrs} . / \mathrm{day} \text { for } 4 \text { months }\end{array}$ & $\begin{array}{l}\text { same } \\
25,000 \mathrm{Btu} / \mathrm{hr} \text {. } \\
\text { same } \\
\text { same } \\
16,250 \mathrm{Btu} / \mathrm{hr} \text {. } \\
\text { same } \\
\text { same } \\
\text { same }\end{array}$ \\
\hline $\begin{array}{l}\text { Water heater and } \\
\text { refrigerator }\end{array}$ & $\begin{array}{l}\text { Water heater fuel } \\
\text { Capacity (in gal.) } \\
\text { Energy factor (EF) } \\
\text { Water heater temperature setting } \\
\text { Annual energy use by refrigerator }\end{array}$ & $\begin{array}{l}\text { electricity } \\
40 \text { gal. } \\
.86 \\
\text { medium } \\
1155 \mathrm{kWh}\end{array}$ & $\begin{array}{l}\text { same } \\
\text { same } \\
.80 \\
\text { medium-high } \\
1500 \mathrm{kWh} \\
\end{array}$ \\
\hline $\begin{array}{l}\text { Existing insulation } \\
\text { levels }\end{array}$ & $\begin{array}{l}\text { Attic insulation } \\
\text { Wall insulation } \\
\text { Floor insulation }\end{array}$ & $\begin{array}{l}\text { R-9 } \\
\text { R-7 } \\
\text { R-0 } \\
\end{array}$ & $\begin{array}{l}\text { R-6 } \\
\text { R-0 } \\
\text { R-0 } \\
\end{array}$ \\
\hline $\begin{array}{l}\text { Climate and } \\
\text { occupancy }\end{array}$ & $\begin{array}{l}\text { Heating degree days } \\
\text { Cooling degree days } \\
\text { Number of occupants, by age: } \\
\qquad-5 \\
6-13 \\
14-64 \\
\text { over } 64\end{array}$ & $\begin{array}{l}1 \\
1 \\
1 \\
0\end{array}$ & $\begin{array}{l}\text { same } \\
\text { same } \\
\text { same } \\
\text { same }\end{array}$ \\
\hline
\end{tabular}


As shown in Figure 4, slightly less than one-third of the total on-site energy used in this house is for heating, in contrast to the typical home in the Northeast and other regions with substantially colder climates. Major appliances account for nearly one-fourth of whole-house energy consumption, miscellaneous functions use another one-fifth of the house's energy, and hot water accounts for almost 15 percent of whole-house energy use. Please note that the number of occupants in this house is lower than in the Northeast and West. This leads to somewhat lower rates of appliance and hot water usage than is the case with larger families. Differences in usage based on household size will occur in all regions.

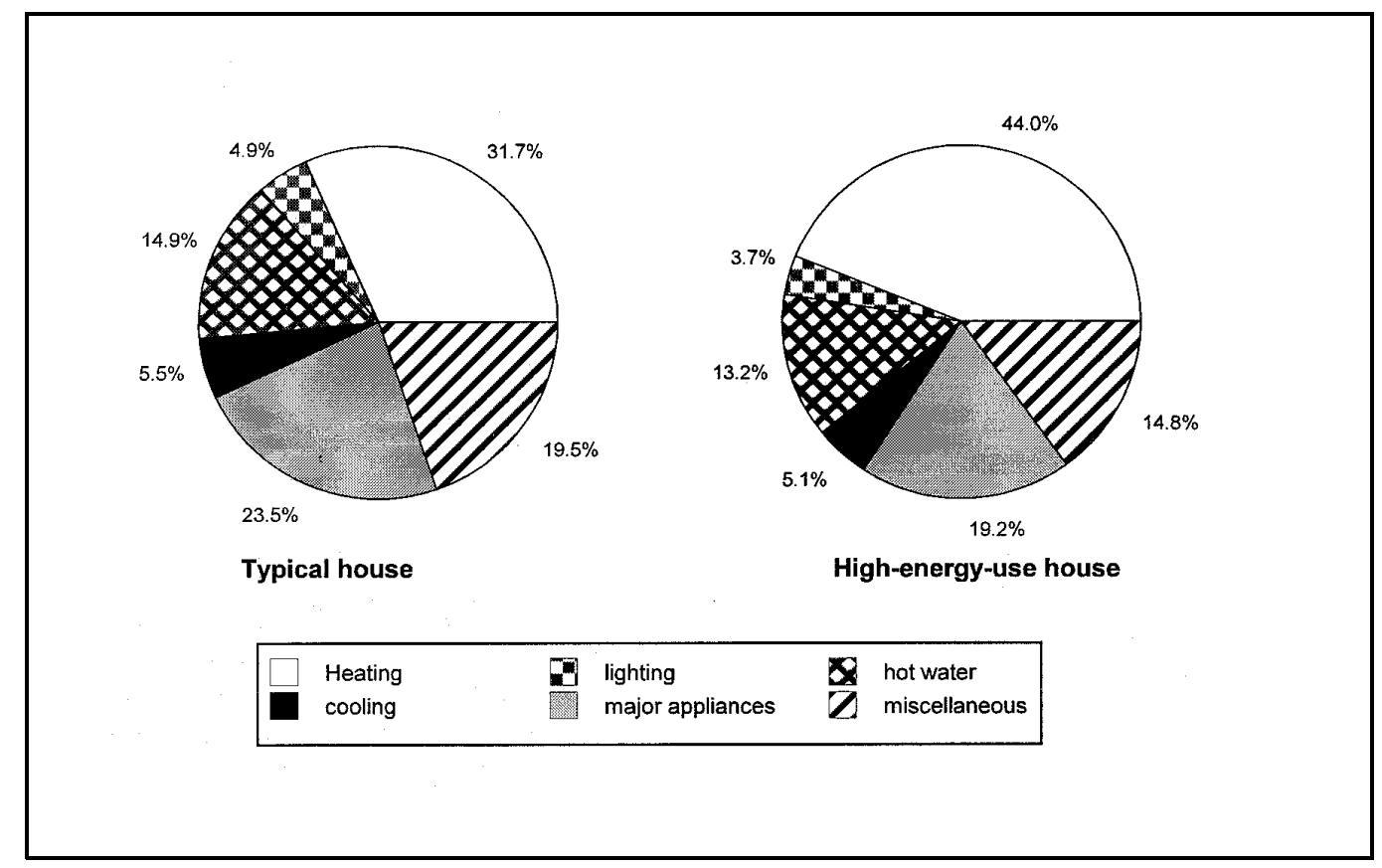

Figure 4. Components of whole-house on-site energy use in South.

\section{High-Energy-Use House}

The high-energy-use house in the South has many of the same characteristics as the typical low-income house described above. The key differences are the size of the conditioned floor area (1875 square feet), the capacity of the heating and cooling systems $(25,000$ and 16,250 Btu per hour, respectively), the energy factor (.80) and temperature setting (medium-high) of the water heater, and the insulation levels (R-6 in the attic and R-0 in the walls). Also, there is 35 percent greater air infiltration than in the typical unit. Other differences between this house and the typical low-income dwelling in this region are shown in Table 3. 
The high-energy-use house in the South uses just over 44 percent of its total on-site energy for heating, which is a higher percentage than in the typical southern house but still substantially less than in the high-energy-use houses in the Northeast and Midwest. The fraction of whole-house energy used for cooling is largely unchanged, while the proportions devoted to all other functions are slightly less than in the typical dwelling (Figure 4).

\section{MIDWEST}

\section{Typical House}

The typical low-income house in Moline, Illinois, was built in 1925, has two stories and a conditioned basement, and contains 2200 square feet of conditioned floor area. This unit has substantially greater floor space than the typical houses in any of the other census regions. Existing attic insulation has a value of R-6 and there is no wall or floor insulation. This dwelling is heated by a central gas forced air unit and also uses gas as the fuel for its water heater. The water heater has an energy factor of .54 and its temperature is set to medium-low. This city is almost as cold as the previously-described city in the Northeast, having an average of 6410 heating degree days per year. Other characteristics of this house are shown in Table 4.

As shown in Figure 5, nearly 80 percent of the whole-house on-site energy used in this house goes for heating, a fact which can be explained by the relatively cold climate, the large size of the dwelling unit, and the low efficiency of the heating system. Major appliances account for almost 10 percent of whole-house energy consumption, and hot water uses just over seven percent of the whole-house on-site energy. Compared to these components, other applications use relatively little energy in this house.

\section{High-Energy-Use House}

The high-energy-use house in the Midwest is very similar to the typical low-income house in this region. The key differences are in the size of the conditioned floor area (2750 square feet, including the conditioned basement), the energy factor (.50) and temperature setting (medium-high) of the water heater, and the insulation level in the attic (R-3). Also, as in all the high-energy-use houses, air infiltration is 35 percent greater than in the typical unit. Other differences between this house and the typical low-income dwelling in this region are shown in Table 4.

Just over 80 percent of the on-site energy used in the high-energy-use house is for heating, which is slightly greater than in the typical house (Figure 5). The fractions of total on-site energy used for major appliances, hot water, lighting, and miscellaneous functions are all a little less than in the typical dwelling. 
Table 4. Key characteristics of typical and high-energy-use houses in Midwest

\begin{tabular}{|c|c|c|c|}
\hline & Characteristics & Typical House & High-Energy-Use House \\
\hline \multirow{8}{*}{ General description } & Year built & 1925 & same \\
\hline & Number of stories & 2 & same \\
\hline & Conditioned floor area & 2200 sq. ft. & 2750 sq. ft. \\
\hline & Type of foundation & conditioned basement & same \\
\hline & Type of exterior siding & wood & same \\
\hline & Number of windows & 20 & 25 \\
\hline & $\begin{array}{l}\text { Window frame and } \\
\text { glazing type }\end{array}$ & wood, single-pane, clear & same \\
\hline & Movable window shades & interior venetian blinds & none \\
\hline \multirow{4}{*}{$\begin{array}{c}\text { Heating and cooling } \\
\text { system }\end{array}$} & $\begin{array}{l}\text { Heating fuel and system } \\
\text { type }\end{array}$ & central gas furnace & same \\
\hline & Heating system capacity & $95,000 \mathrm{Btu} / \mathrm{hr}$ & same \\
\hline & $\begin{array}{l}\text { Efficiency of heating } \\
\text { system }\end{array}$ & 60 & 59 \\
\hline & Cooling system type & none (except fan) & same \\
\hline \multirow{5}{*}{$\begin{array}{l}\text { Water heater and } \\
\text { refrigerator }\end{array}$} & Water heater fuel & gas & same \\
\hline & Capacity (in gal.) & 30 & same \\
\hline & Energy factor (EF) & .54 & .50 \\
\hline & $\begin{array}{l}\text { Water heater temperature } \\
\text { setting }\end{array}$ & medium-low & medium-high \\
\hline & $\begin{array}{l}\text { Annual energy use by } \\
\text { refrigerator }\end{array}$ & $1155 \mathrm{kWh}$ & $1500 \mathrm{kWh}$ \\
\hline \multirow{3}{*}{$\begin{array}{c}\text { Existing Insulation } \\
\text { Levels }\end{array}$} & Attic insulation & $\mathrm{R}-6$ & $\mathrm{R}-3$ \\
\hline & Wall insulation & $\mathrm{R}-0$ & $\mathrm{R}-0$ \\
\hline & Floor insulation & $\mathrm{R}-0$ & $\mathrm{R}-0$ \\
\hline \multirow{6}{*}{ Climate and Occupancy } & Heating degree days & 6410 & same \\
\hline & Number of occupants, by a & & \\
\hline & $0-5$ & 1 & same \\
\hline & $6-13$ & 1 & same \\
\hline & $14-64$ & 1 & same \\
\hline & over 64 & 0 & same \\
\hline
\end{tabular}




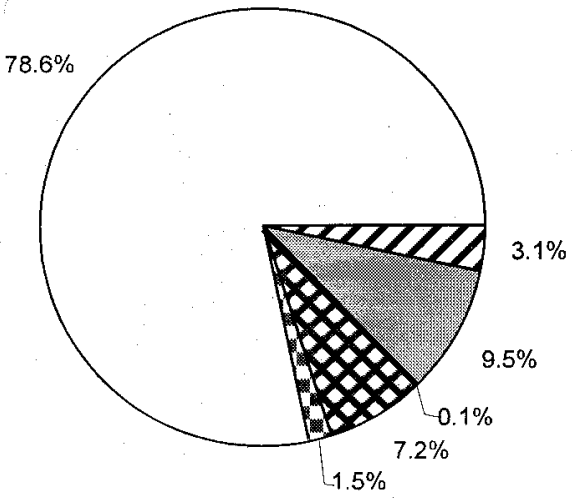

Typical house

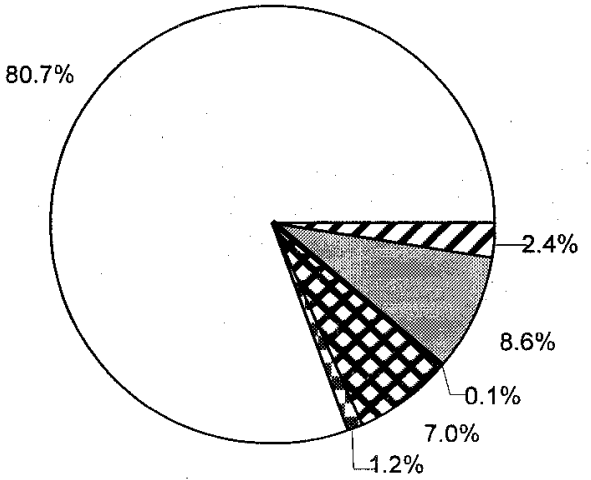

High-energy-use house

$\begin{array}{llll}\text { Heating } & \text { lighting } & \mathbf{B} & \text { hot water } \\ \text { cooling } & \square & \text { miscellaneous }\end{array}$

Figure 5. Components of whole-house on-site energy use in Midwest.

\section{WEST}

\section{Typical House}

In Eureka, California, the typical low-income house was built in 1955, has one story over a vented crawlspace, and contains 950 square feet of conditioned floor area. There is existing attic insulation with a value of R-11 ${ }^{15}$ but no insulation in the walls and floors. This dwelling is heated by a wall gas furnace and also uses gas to heat domestic hot water. The water heater has an energy factor of .54 and its temperature is set to medium-high. The Western city averages 4640 heating degree days per year, putting it approximately half way between the coldest and warmest cities examined in this study. Other characteristics of this house are shown in Table 5.

As shown in Figure 6, slightly less than one-fourth of the whole-house on-site energy consumed in this house is for heating, while hot water accounts for nearly one-third of wholehouse energy consumption and major appliances use over one-fourth of the whole-house on-site

\footnotetext{
${ }^{15}$ Many houses served by the weatherization program in this area have higher insulation levels than this in the attic, but R-11 was chosen to make this house more similar to the houses studied in the other regions.
} 
Table 5. Key characteristics of typical and high-energy-use houses in West

\begin{tabular}{|c|c|c|c|}
\hline & Characteristics & Typical House & High-Energy-Use House \\
\hline \multirow{8}{*}{ General description } & Year built & 1955 & same \\
\hline & Number of stories & 1 & same \\
\hline & Conditioned floor area & 950 sq. ft. & 1200 sq. ft. \\
\hline & Type of foundation & vented crawlspace & same \\
\hline & Type of exterior siding & wood & same \\
\hline & Number of windows & 9 & 12 \\
\hline & $\begin{array}{l}\text { Window frame and glazing } \\
\text { type }\end{array}$ & $\begin{array}{l}\text { wood, single-pane, } \\
\text { clear }\end{array}$ & same \\
\hline & Movable window shades & interior drapes & interior venetian blinds \\
\hline \multirow{4}{*}{$\begin{array}{l}\text { Heating and cooling } \\
\text { systems }\end{array}$} & Heating fuel and system type & wall gas furnace & same \\
\hline & Heating system capacity & $75,000 \mathrm{Btu} / \mathrm{hr}$. & same \\
\hline & Efficiency of heating system & 65 & 64 \\
\hline & Cooling system type & none (except fan) & same \\
\hline \multirow{5}{*}{$\begin{array}{l}\text { Water heater and } \\
\text { refrigerator }\end{array}$} & Water heater fuel & gas & same \\
\hline & Capacity (in gal.) & 40 & same \\
\hline & Energy factor (EF) & .54 & .50 \\
\hline & $\begin{array}{l}\text { Water heater temperature } \\
\text { setting }\end{array}$ & medium-high & same \\
\hline & $\begin{array}{l}\text { Annual energy use by } \\
\text { refrigerator }\end{array}$ & $1155 \mathrm{kWh}$ & $1500 \mathrm{kWh}$ \\
\hline \multirow{3}{*}{$\begin{array}{c}\text { Existing insulation } \\
\text { levels }\end{array}$} & Attic insulation & $\mathrm{R}-11$ & $\mathrm{R}-6$ \\
\hline & Wall insulation & $\mathrm{R}-0$ & same \\
\hline & Floor insulation & $\mathrm{R}-0$ & same \\
\hline \multirow{6}{*}{ Climate and Occupancy } & Heating degree days & 4640 & same \\
\hline & Number of occupants, by age: & & \\
\hline & $0-5$ & 2 & same \\
\hline & $6-13$ & 1 & same \\
\hline & $14-64$ & 2 & same \\
\hline & $0-64$ & 0 & same \\
\hline
\end{tabular}




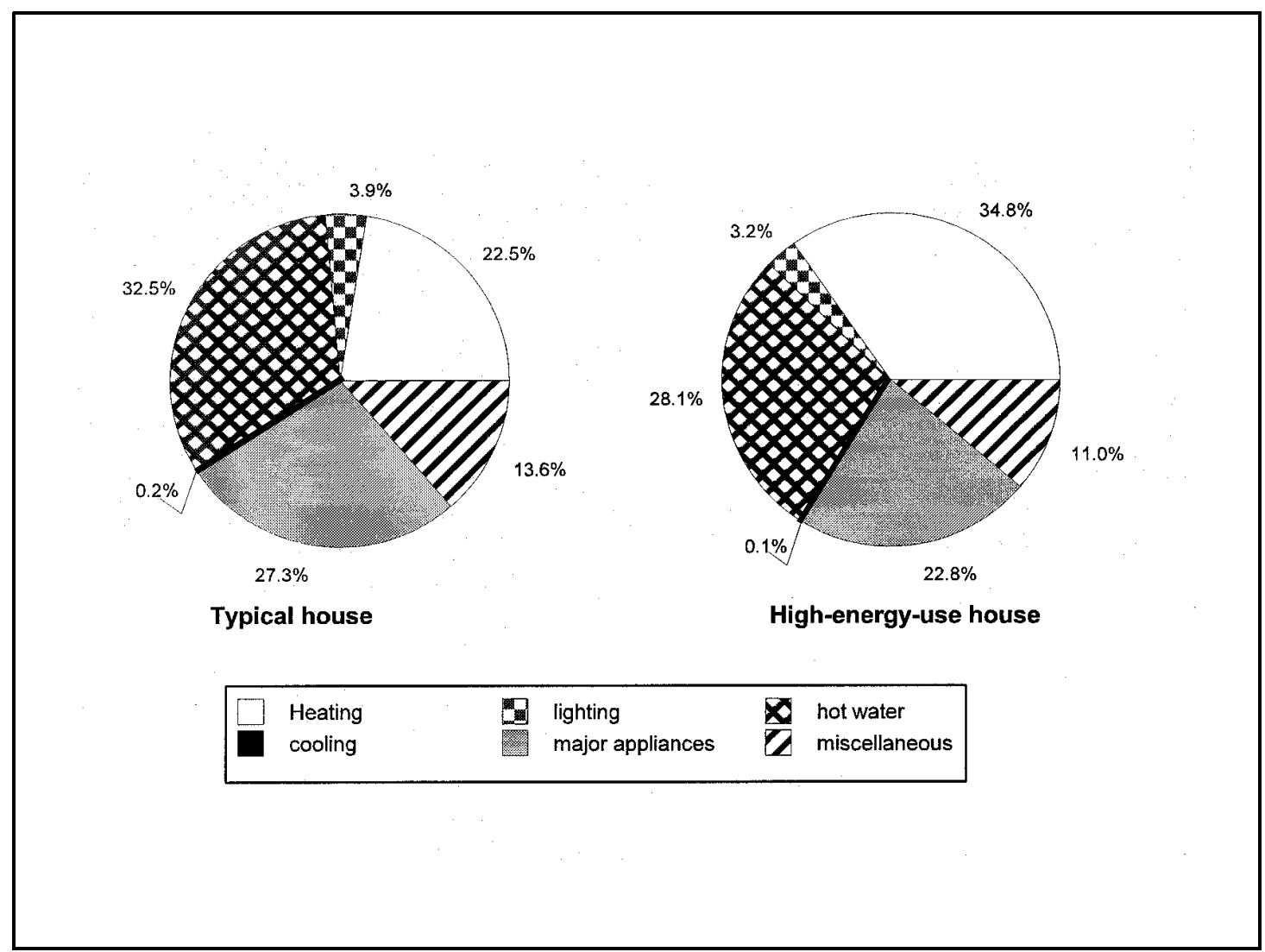

Figure 6. Components of whole-house on-site energy use in West.

energy. The relatively small proportion of total energy used for heating is largely explained by the small floor area of this house. The relative mildness of the climate (compared to the Northeast and Midwest) and the nature of the heating system (a wall furnace) also helps explain why heating does not account for a higher proportion of total energy consumption.

\section{High-Energy-Use-House}

The high-energy-use house in the West has many of the same characteristics as the typical low-income house in this region. Key differences, however, are the size of the conditioned floor area (1200 square feet), the energy factor of the water heater (.50), and the insulation level in the attic (R-6). As always, air infiltration in the high-energy use house is 35 percent greater than in the typical unit. Other differences between this house and the typical low-income dwelling are shown in Table 5.

Slightly more than one-third of the on-site energy used in the high-energy-use house is for heating, substantially more than in the typical house (Figure 6). To compensate for this, the proportion of total energy used for all other applications is slightly lower here than in the typical dwelling. 



\section{PREDICTED EFFECTS OF WEATHERIZATION MEASURES ON SAMPLE HOUSES}

This chapter examines the energy savings (in terms of both site and source Btus), fuel bill reductions, and decreases in $\mathrm{CO}_{2}$ emissions that could be achieved as a result of installing various weatherization measures in the sample houses described in Chapter 3. It is important to note that the discussion of weatherization measures, savings, and costs presented in this chapter is based on the assumption that the houses being weatherized are structurally sound prior to the initiation of weatherization efforts. In reality, many of the low-income houses served by weatherization agencies around the country require at least some amount of pre-weatherization repairs before the types of energy-saving measures discussed in this chapter can be installed. Weatherization agencies in the four cities examined in this study often make a variety of preweatherization minor repairs in the houses that they serve. These can include: various repairs to damaged windows and doors and their frames; actual replacement of old windows and doors; repair of holes in walls, floors, ceilings, and siding; replacement of interior drywall board; repair of attic hatches; and installation of attic venting. The cost of these improvements can range from one or two hundred dollars to over $\$ 1000$ per house. They are not included by the program as efficiency investments for purposes of measuring cost effectiveness and are therefore not discussed further in this report.

The weatherization measures typically installed in each city, along with the associated $\operatorname{costs}^{16}$, were provided by the state and local weatherization staff responsible for program implementation. Other energy-efficiency measures were added to the lists provided by the state and local respondents, based on the literature cited in Chapter 2 on new approaches to reducing baseload electricity use and on information provided by the Home Energy Saver system. Only those measures with a SIR of 1.0 or greater were used and, in general, those measures expected to yield the greatest on-site energy savings were selected first. Overhead costs were added to labor and material expenditures for each package of measures to yield total costs. Projected savings for most of the weatherization measures were provided by Home Energy Saver and were adjusted to reflect the fact that engineering estimates tend to overstate the actual savings achieved in the residential sector. According to the literature review we conducted for this study, an adjustment factor of 0.60 seems appropriate to use for residential direct assistance programs. This means that the estimated savings provided by Home Energy Saver were multiplied by 0.60 to reflect the fact that actual residential savings commonly amount to about 60 percent of the savings predicted.

The cost savings described in this chapter are based on the fuel prices reported by weatherization staff in summer 2000. ${ }^{17}$ Since the time these data were collected, natural gas

\footnotetext{
${ }^{16}$ The costs of individual measures for typical houses provided by weatherization staff were adjusted upward for the high-energy-use houses in proportion to their greater size and the increased amounts of labor and material required to bring them up to the desired level.

${ }^{17}$ In the case of Birmingham, Alabama, the default price of electricity provided by Home Energy Saver was used.
} 
prices rose substantially nationwide and remained high throughout most of 2001. As of early 2002, prices have declined considerably from their highest point and the current national average price for natural gas is slightly lower than it was when we gathered our fuel price information. Average electricity prices also have fluctuated during the same period, but the magnitude of the change has been much less. The current average price of electricity is about the same as it was when the data used in this study were gathered. In the short-term future (U.S. Energy Information Administration 2002), prices are projected to continue to go up and down, but not nearly as dramatically as in the recent past. The latest long-term projections from the U.S. Energy Information Administration (December 2001) show that the average prices of natural gas and electricity in 2020 are expected to be slightly less than they were in 2000 . However, recent experience has shown that projections of future energy prices (especially for the near term) have considerable uncertainty attached to them.

As in Chapter 3, the typical and high-energy-use houses are discussed separately for each of the four census regions. For several of the houses, the discussion is further separated into two parts, one explaining what could be accomplished with a package of measures costing roughly $\$ 2500$ (including overhead) and the other exploring the savings associated with an expanded package of measures ${ }^{18}$. In one case (the typical house in the West), there were relatively few weatherization measures that passed the required cost-effectiveness test, so the actual cost of the “\$2500 package” was substantially less than $\$ 2500$.

\section{NORTHEAST}

\section{Typical House}

\$2500 Package. The specific measures to be taken in the typical house in the Northeast are listed in Table 6, along with their costs, predicted savings in million Btus (MBtus), and emissions reductions. Overall, the total fuel bill would be reduced by 15.5 percent, consumption of site Btus would drop by 21.8 percent, 17.1 percent fewer Btus would be used at the generation source, and $\mathrm{CO}_{2}$ emissions would fall by 17.6 percent. The actual cost of the full package of weatherization measures would be just over $\$ 2580$. The measure expected to yield the greatest savings in terms of all four units of measurement used in this study (i.e., fuel bills, site Btus, source Btus, bills, and $\mathrm{CO}_{2}$ emissions) is air sealing to reduce infiltration ${ }^{19}$. Installing attic and wall insulation, changing the water heater temperature setting from medium-high to mediumlow, and installing a programmable thermostat on the central heating system would result in

\footnotetext{
18 An expanded package of cost-effective measures was identified that would offer substantial additional savings in two of the four typical houses (Northeast and Midwest) and three of the four high-energy-use houses (Northeast, South, and Midwest). The total costs of these expanded packages range from $\$ 3250$ for the typical house in the Midwest to $\$ 5603$ for the high-energy-use house in the Northeast.

19 This consists of taking actions (like installing caulking and weatherstripping) that are designed to reduce the flow of air between the conditioned space of the house and the unconditioned area surrounding it.
} 
Table 6. Weatherization measures, costs, and savings for typical house in Northeast

\begin{tabular}{|c|c|c|c|c|c|c|}
\hline \multirow[t]{2}{*}{$\begin{array}{c}\text { Base Case } \\
\text { (Unweatherized House) }\end{array}$} & & & $\begin{array}{c}\text { Total fuel } \\
\text { bill }\end{array}$ & $\begin{array}{c}\text { Total site } \\
\text { MBtus }\end{array}$ & $\begin{array}{c}\text { Total } \\
\text { source } \\
\text { MBtus } \\
\end{array}$ & $\begin{array}{l}\text { Total } \mathrm{CO}_{2} \\
\text { emissions (in } \\
\text { pounds) }\end{array}$ \\
\hline & & & $\$ 2,373$ & 173.3 & 252.7 & 28,020 \\
\hline \multirow{6}{*}{ Weatherization } & Measure name & $\begin{array}{l}\text { Measure } \\
\text { cost }(\$)\end{array}$ & $\begin{array}{c}\text { Fuel bill } \\
\text { savings }(\$)\end{array}$ & $\begin{array}{l}\text { Site MBtu } \\
\text { savings }\end{array}$ & $\begin{array}{l}\text { Source } \\
\text { MBtu } \\
\text { savings }\end{array}$ & $\begin{array}{c}\mathrm{CO}_{2} \\
\text { reductions } \\
\text { (in pounds) }\end{array}$ \\
\hline & 1. Air sealing & 310 & 135 & 14.4 & 16 & 1837 \\
\hline & $\begin{array}{l}\text { 2. Reset water heater } \\
\text { thermostat (from med-high to } \\
\text { med-low) }\end{array}$ & 10 & 45 & 5.6 & 5.6 & 652 \\
\hline & $\begin{array}{l}\text { 3. Water heater wrap (from EF } \\
54 \text { to EF 56) }\end{array}$ & 30 & 5 & 0.7 & 0.7 & 77 \\
\hline & $\begin{array}{l}\text { 4. Programmable thermostat } \\
\text { for heating system }\end{array}$ & 110 & 32 & 3.6 & 3.9 & 446 \\
\hline & $\begin{array}{l}\text { 5. Attic insulation (from R6 to } \\
\text { R38) }\end{array}$ & 720 & 65 & 7.1 & 7.7 & 892 \\
\hline \multirow[t]{6}{*}{ Package } & $\begin{array}{l}\text { 6. Wall insulation (from } \mathrm{R} 7 \text { to } \\
\text { R13) }\end{array}$ & 650 & 39 & 4.3 & 4.6 & 536 \\
\hline & $\begin{array}{l}\text { 7. Low-flow shower head and } \\
\text { insulate water heater pipes }\end{array}$ & 50 & 10 & 1.2 & 1.2 & 140 \\
\hline & $\begin{array}{l}\text { 8. Compact fluorescent bulbs } \\
\text { (5) }\end{array}$ & 75 & 38 & 1.1 & 3.4 & 356 \\
\hline & Overhead (32\%) & 626 & & & & \\
\hline & Sum & $\$ 2,581$ & $\$ 369$ & 37.9 & 43.1 & 4935 \\
\hline & Percent Savings & & $15.5 \%$ & $21.8 \%$ & $17.1 \%$ & $17.6 \%$ \\
\hline Expanded & $\begin{array}{l}\text { 9. Replace refrigerator (from } \\
1155 \mathrm{kWh} / \mathrm{yr} \text {. to } 479 \mathrm{kWh} / \mathrm{yr} \text { ) }\end{array}$ & 650 & 81 & 2.3 & 7.4 & 764 \\
\hline Weatherization & Overhead (32\%) & 208 & & & & \\
\hline \multirow[t]{2}{*}{ Package } & Sum & $\$ 3,439$ & $\$ 450$ & 40.2 & 50.5 & 5699 \\
\hline & Percent Savings & & $19.0 \%$ & $23.2 \%$ & $20.0 \%$ & $20.3 \%$ \\
\hline
\end{tabular}

substantial savings in terms of on-site energy use. Installation of compact fluorescent bulbs would lead to substantial dollar savings but would not compare to the previously-mentioned measures in terms of on-site energy savings.

Expanded Package. This would include all the measures listed above plus replacing the existing refrigerator with a more energy-efficient unit. This would increase savings to 19.0 percent of the fuel bill, 23.2 percent of site Btus, 17.1 percent of source Btus, and 17.6 percent of $\mathrm{CO}_{2}$ emissions (Table 6). It also would increase total costs to $\$ 3439$. As with installation of compact fluorescent bulbs, refrigerator replacement is much more effective at saving money and source Btus than at reducing on-site energy consumption. 


\section{High-Energy-Use House}

\$2500 Package. Table 7 shows that the savings achieved by this package of measures would be greater than for the typical house in this region. Fuel bill savings would reach 18.7 percent; site Btu savings would amount to 24.6 percent; source Btu savings would be 20.3 percent; and $\mathrm{CO}_{2}$ emission reductions would equal 20.9 percent. The actual cost for the entire package of measures needed to achieve these savings would be $\$ 2732$, as compared to the

Table 7. Weatherization measures, costs, and savings for high-energy-use house in Northeast

\begin{tabular}{|c|c|c|c|c|c|c|}
\hline \multirow{2}{*}{$\begin{array}{c}\text { Base Case } \\
\text { (Unweatherized } \\
\text { House) }\end{array}$} & & & $\begin{array}{c}\text { Total fuel } \\
\text { bill }\end{array}$ & $\begin{array}{c}\text { Total site } \\
\text { MBtus }\end{array}$ & $\begin{array}{c}\text { Total } \\
\text { source } \\
\text { MBtus } \\
\end{array}$ & $\begin{array}{c}\text { Total } \mathrm{CO}_{2} \\
\text { emissions (in } \\
\text { pounds) }\end{array}$ \\
\hline & & & $\$ 3,339$ & 278.3 & 368.0 & 41,283 \\
\hline \multirow{8}{*}{$\begin{array}{c}\quad \$ 2,500 \\
\text { Weatherization } \\
\text { Package }\end{array}$} & Measure name & $\begin{array}{c}\text { Measure } \\
\text { cost }(\$)\end{array}$ & $\begin{array}{l}\text { Fuel bill } \\
\text { savings } \\
\text { (\$) }\end{array}$ & $\begin{array}{l}\text { Site MBtu } \\
\text { savings }\end{array}$ & $\begin{array}{c}\text { Source } \\
\text { MBtu } \\
\text { savings }\end{array}$ & $\begin{array}{c}\mathrm{CO}_{2} \\
\text { reductions } \\
\text { (in pounds) }\end{array}$ \\
\hline & 1. Air sealing & 420 & 232 & 24.9 & 27.5 & 3160 \\
\hline & $\begin{array}{l}\text { 2. Reset water heater } \\
\text { thermostat (from med- } \\
\text { high to med-low) }\end{array}$ & 10 & 47 & 5.9 & 5.9 & 693 \\
\hline & $\begin{array}{l}\text { 3. Wall insulation (from } \\
\text { R0 to R13) }\end{array}$ & 1,590 & 338 & 36.5 & 40.2 & 4629 \\
\hline & $\begin{array}{l}\text { 4. Low-flow shower } \\
\text { head and insulate water } \\
\text { heater pipes }\end{array}$ & 50 & 9 & 1.1 & 1.1 & 128 \\
\hline & Overhead (32\%) & 662 & & & & \\
\hline & Sum & $\$ 2,732$ & $\$ 626$ & 68.5 & 74.8 & 8610 \\
\hline & Percent Savings & & $18.7 \%$ & $24.6 \%$ & $20.3 \%$ & $20.9 \%$ \\
\hline \multirow{8}{*}{$\begin{array}{l}\text { Expanded } \\
\text { Weatherization }\end{array}$} & $\begin{array}{l}\text { 5. Programmable } \\
\text { thermostat for heating } \\
\text { system }\end{array}$ & 110 & 40 & 4.6 & 4.9 & 565 \\
\hline & $\begin{array}{l}\text { 6. Attic insulation (from } \\
\text { R3 to R38) }\end{array}$ & 980 & 134 & 14.2 & 15.8 & 1816 \\
\hline & $\begin{array}{l}\text { 7. Replace water heater } \\
\text { (EF50 to EF62) }\end{array}$ & 360 & 31 & 4.0 & 4.0 & 463 \\
\hline & $\begin{array}{l}\text { 8. Compact fluorescent } \\
\text { bulbs (5) }\end{array}$ & 75 & 38 & 1.1 & 3.4 & 356 \\
\hline & $\begin{array}{l}\text { 9. Replace refrigerator } \\
\text { (from } 1500 \mathrm{kWh} / \mathrm{yr} \text {. to } \\
479 \mathrm{kWh} / \mathrm{yr} \text {.) }\end{array}$ & 650 & 123 & 3.5 & 11.1 & 1154 \\
\hline & Overhead (32\%) & 696 & & & & \\
\hline & Sum & $\$ 5,603$ & $\$ 992$ & 95.8 & 113.9 & 12,964 \\
\hline & Percent Savings & & $29.7 \%$ & $34.4 \%$ & $31.0 \%$ & $31.4 \%$ \\
\hline
\end{tabular}


$\$ 2581$ required for the typical house. The energy efficiency improvements expected to result in the highest savings according to all four units of measurement are air sealing and installing wall insulation.

Expanded Package. This would include the four measures listed above plus installing a programmable thermostat, attic insulation, and compact fluorescent bulbs and replacing the existing water heater and refrigerator with more energy-efficient units. The installation of compact fluorescent bulbs and refrigerator replacement have a much greater effect on fuel bill and source Btu savings than on site Btu reductions because the cost of electricity is much higher per site Btu than the cost of gas and it requires roughly three Btus at the generation source to produce every site Btu of electricity. Installing all the additional measures listed above would boost the total cost to $\$ 5603$ but would also substantially increase savings, to 29.7 percent of the fuel bill, 34.4 percent of site Btus, 31.0 percent of source Btus, and 31.4 percent of $\mathrm{CO}_{2}$ emissions (Table 7). If everything was done except replacing the water heater and refrigerator, total costs would fall to $\$ 4270$ and savings would amount to 25.1 percent of the bill, 31.7 percent of site Btus, 26.8 percent of source Btus, and 27.5 percent of $\mathrm{CO}_{2}$ emissions.

\section{SOUTH}

\section{Typical House}

\$2500 Package. Table 8 shows the specific measures to be taken in the typical house in the South, along with their costs and predicted savings. The savings that would be achieved here are substantially lower than in the Northeast or Midwest, primarily due to the fact that heating accounts for a smaller portion of energy use in the South than in those other regions. Overall, the total fuel bill, consumption of site and source Btus, and $\mathrm{CO}_{2}$ emissions would all fall by 15.2 percent. Unlike the other cities studied, the savings percentages are essentially the same here regardless of the unit of measurement employed because electricity is the only fuel used. The total cost of the full package of weatherization measures would be $\$ 2370$. The measures expected to yield the greatest savings are air sealing, replacing the old refrigerator, attic insulation, resetting the water heater temperature from medium to medium-low, and replacing incandescent light bulbs with compact fluorescent ones.

The replacement of room air conditioners with more efficient units is not a measure examined in this study. This is because it is not typically employed in the region by the Weatherization Program nor is it commonly listed among the cost effective measures that can be taken in the Home Energy Saver model.

Expanded Package. No additional measures were found to be cost-effective for the typical house in this city. 
Table 8. Weatherization measures, costs, and savings for typical house in South

\begin{tabular}{|c|c|c|c|c|c|c|}
\hline \multirow{2}{*}{$\begin{array}{c}\text { Base Case } \\
\text { (Unweatherized } \\
\text { House) }\end{array}$} & & & $\begin{array}{c}\text { Total fuel } \\
\text { bill }\end{array}$ & $\begin{array}{c}\text { Total site } \\
\text { MBtus }\end{array}$ & $\begin{array}{l}\text { Total } \\
\text { source } \\
\text { MBtus }\end{array}$ & $\begin{array}{c}\text { Total } \mathrm{CO}_{2} \\
\text { emissions (in } \\
\text { pounds) }\end{array}$ \\
\hline & & & $\$ 1,522$ & 82.4 & 262.9 & 40,716 \\
\hline \multirow{11}{*}{ Weatherization } & Measure name & $\begin{array}{l}\text { Measure } \\
\text { cost }(\$)\end{array}$ & $\begin{array}{l}\text { Fuel bill } \\
\text { savings } \\
\text { (\$) }\end{array}$ & $\begin{array}{c}\text { Site } \\
\text { MBtu } \\
\text { savings }\end{array}$ & $\begin{array}{c}\text { Source } \\
\text { MBtu } \\
\text { savings }\end{array}$ & $\begin{array}{c}\mathrm{CO}_{2} \\
\text { reductions } \\
\text { (in pounds) }\end{array}$ \\
\hline & 1. Air sealing & 380 & 74 & 4.0 & 12.8 & 1982 \\
\hline & $\begin{array}{l}\text { 2. Reset water heater } \\
\text { thermostat (from } \\
\text { medium to med-low) }\end{array}$ & 10 & 25 & 1.3 & 4.2 & 646 \\
\hline & $\begin{array}{l}\text { 3. Water heater wrap } \\
\text { (from EF86 to } \\
\text { EF 88) }\end{array}$ & 35 & 4 & 0.2 & 0.8 & 117 \\
\hline & $\begin{array}{l}\text { 4. Attic insulation } \\
\text { (from R9 to R38) }\end{array}$ & 720 & 55 & 3.0 & 9.5 & 1476 \\
\hline & $\begin{array}{l}\text { 5. Low-flow shower } \\
\text { head and insulate } \\
\text { water heater pipes }\end{array}$ & 50 & 11 & 0.6 & 1.9 & 297 \\
\hline & $\begin{array}{l}\text { 6. Compact } \\
\text { fluorescent bulbs (5) }\end{array}$ & 75 & 20 & 1.1 & 3.4 & 531 \\
\hline & $\begin{array}{l}\text { 7. Replace } \\
\text { refrigerator (from } \\
1155 \mathrm{kWh} / \mathrm{yr} \text { to } \\
479 \mathrm{kWh} / \mathrm{yr} \text {.) }\end{array}$ & 650 & 43 & 2.3 & 7.4 & 1140 \\
\hline & Overhead (\$450) & 450 & & & & \\
\hline & Sum & $\$ 2,370$ & $\$ 232$ & 12.5 & 40.0 & 6190 \\
\hline & Percent Savings & & $15.2 \%$ & $15.2 \%$ & $15.2 \%$ & $15.2 \%$ \\
\hline
\end{tabular}

\section{High-Energy-Use House}

\$2500 Package. The savings resulting from this package of measures would amount to 15.9 percent according to each of the measurements used in this study. This is slightly greater than the savings that would be achieved in the typical house. The energy efficiency improvements expected to result in the highest savings are air sealing, installing wall and attic insulation, and resetting the water heater temperature from medium-high to medium-low. The entire package of measures would cost $\$ 2725$. 
Expanded Package. This would include all the measures listed above plus installing a low-flow shower head and compact fluorescent bulbs and replacing the old refrigerator with an energy-efficient one. As shown in Table 9, these additional measures would increase the total cost to $\$ 3500$ and increase savings to about 20.6 percent.

Table 9. Weatherization measures, costs, and savings for high-energy-use house in South

\begin{tabular}{|c|c|c|c|c|c|c|}
\hline \multirow{2}{*}{$\begin{array}{c}\text { Base Case } \\
\text { (Unweatherized } \\
\text { House) }\end{array}$} & & & $\begin{array}{c}\text { Total fuel } \\
\text { bill }\end{array}$ & $\begin{array}{c}\text { Total site } \\
\text { MBtus }\end{array}$ & $\begin{array}{l}\text { Total } \\
\text { source } \\
\text { MBtus }\end{array}$ & $\begin{array}{c}\text { Total } \mathrm{CO}_{2} \\
\text { emissions (in } \\
\text { pounds) }\end{array}$ \\
\hline & & & $\$ 2,009$ & 108.8 & 347.3 & 53,801 \\
\hline \multirow{9}{*}{$\begin{array}{c}\qquad \mathbf{\$ 2 , 5 0 0} \\
\text { Weatherization }\end{array}$} & Measure name & $\begin{array}{l}\text { Measure } \\
\operatorname{cost}(\$)\end{array}$ & $\begin{array}{c}\text { Fuel bill } \\
\text { savings (\$) }\end{array}$ & $\begin{array}{l}\text { Site MBtu } \\
\text { savings }\end{array}$ & $\begin{array}{c}\text { Source } \\
\text { MBtu } \\
\text { savings }\end{array}$ & $\begin{array}{c}\mathrm{CO}_{2} \\
\text { reductions (in } \\
\text { pounds) }\end{array}$ \\
\hline & 1. Air sealing & 510 & 94 & 5.1 & 16.3 & 2531 \\
\hline & $\begin{array}{l}\text { 2. Reset water heater } \\
\text { thermostat (from med- } \\
\text { high to med-low) }\end{array}$ & 10 & 51 & 2.8 & 8.8 & 1367 \\
\hline & $\begin{array}{l}\text { 3. Water heater wrap } \\
\text { (from EF80 to EF 83) }\end{array}$ & 35 & 7 & 0.4 & 1.3 & 202 \\
\hline & $\begin{array}{l}\text { 4. Attic insulation } \\
\text { (from R6 to R38) }\end{array}$ & 990 & 80 & 4.3 & 14 & 2142 \\
\hline & $\begin{array}{l}\text { 5. Wall insulation (R0 } \\
\text { to R11) }\end{array}$ & 730 & 86 & 4.7 & 15.0 & 2317 \\
\hline & Overhead $(\$ 450)$ & 450 & & & & \\
\hline & Sum & $\$ 2,725$ & $\$ 319$ & $\mathbf{1 7 . 3}$ & 55.2 & 8559 \\
\hline & Percent Savings & & $15.9 \%$ & $15.9 \%$ & $15.9 \%$ & $15.9 \%$ \\
\hline \multirow{6}{*}{ Weatherization } & $\begin{array}{l}\text { 6. Low-flow shower } \\
\text { head and insulate water } \\
\text { heater pipes }\end{array}$ & 50 & 10 & 0.5 & 1.7 & 268 \\
\hline & $\begin{array}{l}\text { 7. Compact fluorescent } \\
\text { bulbs (5) }\end{array}$ & 75 & 20 & 1.1 & 3.4 & 531 \\
\hline & $\begin{array}{l}\text { 8. Replace refrigerator } \\
\text { (from } 1500 \mathrm{kWh} / \mathrm{yr} \text {. to } \\
479 \mathrm{kWh} / \mathrm{yr} \text {.) }\end{array}$ & 650 & 64 & 3.5 & 11.1 & 1721 \\
\hline & & & & & & \\
\hline & Sum & $\$ 3,500$ & $\$ 413$ & 22.4 & 71.5 & 11,079 \\
\hline & Percent Savings & & $20.5 \%$ & $20.6 \%$ & $20.6 \%$ & $20.6 \%$ \\
\hline
\end{tabular}




\section{MIDWEST}

\section{Typical House}

\$2500 Package. The specific measures to be taken in the typical house in the Midwest, along with their costs and predicted savings, are shown in Table 10. The total fuel bill would drop by 20.4 percent, consumption of site Btus would go down by 25.0 percent, the number of Btus used at the generation source would decline by 21.5 percent, and $\mathrm{CO}_{2}$ emissions would fall by 20.1 percent. The actual cost of the full package of weatherization measures would be $\$ 2388$.

The measures expected to result in the greatest savings according to all units of measurement are air sealing, installing wall and attic insulation, and putting a programmable thermostat on the central heating system.

Expanded Package. This would include all the measures listed above plus refrigerator replacement, which adds substantial savings in terms of fuel bills, source Btus, and $\mathrm{CO}_{2}$ emissions. The expanded package would result in savings amounting to 23.2 percent of the fuel bill, 25.9 percent of site Btus, 23.8 percent of source Btus, and 23.1 percent of $\mathrm{CO}_{2}$ emissions (Table 10). Total cost of the package would be $\$ 3200$.

\section{High-Energy-Use House}

\$2500 Package. Table 11 shows that the savings achieved by this package of measures would exceed those found in the typical house in this region. Fuel bill savings would equal 22.7 percent; site Btu savings would reach 26.6 percent; source Btu savings would amount to 23.7 percent; and $\mathrm{CO}_{2}$ emission reductions would be 22.5 percent. The total cost for the entire package of measures needed to achieve these savings would be $\$ 2638$. The energy efficiency improvements expected to result in the highest savings according to all four units of measurement are installing wall and attic insulation, air sealing, and putting in a programmable thermostat for the central heating system.

Expanded Package. This would include all the measures listed above plus installing a greater amount of attic insulation and replacing the old refrigerator and the existing furnace with high-efficiency models. These additional measures would dramatically increase savings, to 33.9 percent of the fuel bill, 37.2 percent of site Btus, 34.7 percent of source Btus, and 33.7 percent of $\mathrm{CO}_{2}$ emissions (Table 11). It would also increase costs to $\$ 7175$. As always, refrigerator replacement is much more effective at saving money and source Btus than at reducing on-site energy consumption. Replacing the old furnace with a highly-efficient new one would result in substantial savings according to all units of measurement but would also be quite expensive. Without that measure, the total cost would be $\$ 4050$ and savings would amount to 26.9 percent of the fuel bill, 28.6 percent of site Btus, 27.3 percent of source Btus, and 26.8 percent of $\mathrm{CO}_{2}$ emissions. 
Table 10. Weatherization measures, costs, and savings for typical house in Midwest

\begin{tabular}{|c|c|c|c|c|c|c|}
\hline \multirow[t]{2}{*}{$\begin{array}{c}\text { Base Case } \\
\text { (Unweatherized } \\
\text { House) }\end{array}$} & & & $\begin{array}{c}\text { Total fuel } \\
\text { bill }\end{array}$ & $\begin{array}{l}\text { Total site } \\
\text { MBtus }\end{array}$ & $\begin{array}{l}\text { Total } \\
\text { source } \\
\text { MBtus }\end{array}$ & $\begin{array}{c}\text { Total } \mathrm{CO}_{2} \\
\text { emissions (in } \\
\text { pounds) }\end{array}$ \\
\hline & & & $\$ 2,134$ & 255.5 & 311.4 & 39,646 \\
\hline \multirow[b]{5}{*}{$\begin{array}{c}\qquad 2,500 \\
\text { Weatherization }\end{array}$} & Measure name & $\begin{array}{l}\text { Measure } \\
\operatorname{cost}(\$)\end{array}$ & $\begin{array}{c}\text { Fuel bill } \\
\text { savings (\$) }\end{array}$ & $\begin{array}{l}\text { Site MBtu } \\
\text { savings }\end{array}$ & $\begin{array}{c}\text { Source } \\
\text { MBtu } \\
\text { savings }\end{array}$ & $\begin{array}{c}\mathrm{CO}_{2} \\
\text { reductions (in } \\
\text { pounds) }\end{array}$ \\
\hline & 1. Air sealing & 420 & 119 & 18.2 & 18.4 & 2170 \\
\hline & $\begin{array}{l}\text { 2. Water heater wrap } \\
\text { (from EF54 to EF56) }\end{array}$ & 25 & 4 & 0.7 & 0.7 & 83 \\
\hline & $\begin{array}{l}\text { 3. Programmable } \\
\text { thermostat for heating } \\
\text { system }\end{array}$ & 70 & 49 & 7.6 & 7.7 & 907 \\
\hline & $\begin{array}{l}\text { 4. Attic insulation } \\
\text { (from R6 to R38) }\end{array}$ & 650 & 55 & 8.6 & 8.7 & 1010 \\
\hline \multirow[t]{6}{*}{ Package } & $\begin{array}{l}\text { 5. Wall insulation } \\
\text { (from R0 to R13) }\end{array}$ & 620 & 171 & 26.2 & 26.5 & 3110 \\
\hline & $\begin{array}{l}\text { 6. Low-flow shower } \\
\text { head and insulate water } \\
\text { heater pipes }\end{array}$ & 50 & 9 & 1.4 & 1.4 & 164 \\
\hline & $\begin{array}{l}\text { 7. Compact fluorescent } \\
\text { bulbs (5) }\end{array}$ & 75 & 28 & 1.1 & 3.4 & 539 \\
\hline & Overhead (25\%) & 478 & & & & \\
\hline & Sum & $\$ 2,388$ & $\$ 435$ & 63.8 & 66.8 & 7983 \\
\hline & Percent Savings & & $20.4 \%$ & $25.0 \%$ & $21.5 \%$ & $20.1 \%$ \\
\hline \multirow{4}{*}{$\begin{array}{c}\text { Expanded } \\
\text { Weatherization } \\
\text { Package }\end{array}$} & $\begin{array}{l}\text { 8. Replace refrigerator } \\
\text { (from } 1155 \mathrm{kWh} / \mathrm{yr} \text {. to } \\
479 \mathrm{kWh} / \mathrm{yr} \text {.) }\end{array}$ & 650 & 60 & 2.3 & 7.4 & 1156 \\
\hline & Overhead (25\%) & 162 & & & & \\
\hline & Sum & $\$ 3,200$ & $\$ 495$ & 66.1 & 74.2 & 9139 \\
\hline & Percent Savings & & $23.2 \%$ & $25.9 \%$ & $23.8 \%$ & $23.1 \%$ \\
\hline
\end{tabular}


Table 11. Weatherization measures, costs, and savings for high-energy-use house in Midwest

\begin{tabular}{|c|c|c|c|c|c|c|}
\hline \multirow{2}{*}{$\begin{array}{c}\text { Base Case } \\
\text { (Unweatherized } \\
\text { House) }\end{array}$} & & & $\begin{array}{l}\text { Total fuel } \\
\text { bill }\end{array}$ & $\begin{array}{l}\text { Total site } \\
\text { MBtus }\end{array}$ & $\begin{array}{l}\text { Total } \\
\text { source } \\
\text { MBtus }\end{array}$ & $\begin{array}{c}\text { Total } \mathrm{CO}_{2} \\
\text { emissions (in } \\
\text { pounds) }\end{array}$ \\
\hline & & & $\$ 2,656$ & 335.5 & 392.5 & 49,189 \\
\hline \multirow{12}{*}{$\begin{array}{c}\$ 2,500 \\
\text { Weatherization } \\
\text { Package }\end{array}$} & Measure name & $\begin{array}{l}\text { Measure } \\
\operatorname{cost}(\$)\end{array}$ & $\begin{array}{c}\text { Fuel bill } \\
\text { savings (\$) }\end{array}$ & $\begin{array}{l}\text { Site MBtu } \\
\text { savings }\end{array}$ & $\begin{array}{c}\text { Source } \\
\text { MBtu } \\
\text { savings }\end{array}$ & $\begin{array}{c}\mathrm{CO}_{2} \\
\text { reductions (in } \\
\text { pounds) }\end{array}$ \\
\hline & 1. Air sealing & 570 & 187 & 28.5 & 29.0 & 3418 \\
\hline & $\begin{array}{l}\text { 2. Reset water heater } \\
\text { thermostat (from med- } \\
\text { high to med-low) }\end{array}$ & 10 & 28 & 4.3 & 4.3 & 505 \\
\hline & $\begin{array}{l}\text { 3. Water heater wrap } \\
\text { (from EF } 50 \text { to } \mathrm{EF} 55 \text { ) }\end{array}$ & 25 & 12 & 1.9 & 1.9 & 224 \\
\hline & $\begin{array}{l}\text { 4. Programmable } \\
\text { thermostat for heating } \\
\text { system }\end{array}$ & 70 & 65 & 9.8 & 10.1 & 1187 \\
\hline & $\begin{array}{l}\text { 5. Attic insulation } \\
\text { (from R3 to R19) }\end{array}$ & 410 & 85 & 13.1 & 13.3 & 1559 \\
\hline & $\begin{array}{l}\text { 6. Wall insulation } \\
\text { (from R0 to R13) }\end{array}$ & 900 & 190 & 29.4 & 29.7 & 3481 \\
\hline & $\begin{array}{l}\text { 7. Low-flow shower } \\
\text { head and insulate water } \\
\text { pipes }\end{array}$ & 50 & 8 & 1.2 & 1.2 & 140 \\
\hline & $\begin{array}{l}\text { 8. Compact fluorescent } \\
\text { bulbs (5) }\end{array}$ & 75 & 28 & 1.1 & 3.4 & 539 \\
\hline & Overhead (25\%) & 528 & & & & \\
\hline & Sum & $\$ 2,638$ & $\$ 603$ & 89.3 & 92.9 & 11,053 \\
\hline & Percent Savings & & $22.7 \%$ & $26.6 \%$ & $23.7 \%$ & $22.5 \%$ \\
\hline \multirow{6}{*}{$\begin{array}{c}\text { Expanded } \\
\text { Weatherization } \\
\text { Package }\end{array}$} & $\begin{array}{l}\text { 9. Attic insulation } \\
\text { (from R19 to R38) }\end{array}$ & 480 & 20 & 3.1 & 3.1 & 365 \\
\hline & $\begin{array}{l}\text { 10. Replace refrigerator } \\
\text { (from } 1500 \mathrm{kWh} / \mathrm{yr} \text { to } \\
479 \mathrm{kWh} / \mathrm{yr} \text {.) }\end{array}$ & 650 & 91 & 3.5 & 11.1 & 1746 \\
\hline & $\begin{array}{l}\text { 11. Replace furnace } \\
\text { (from efficiency of } 59 \\
\text { to } 90 \text { ) }\end{array}$ & 2,500 & 186 & 29.0 & 29.1 & 3399 \\
\hline & Overhead (25\%) & 907 & & & & \\
\hline & Sum & $\$ 7,175$ & $\$ 900$ & 124.9 & 136.2 & 16,563 \\
\hline & Percent Savings & & $33.9 \%$ & $37.2 \%$ & $34.7 \%$ & $33.7 \%$ \\
\hline
\end{tabular}




\section{WEST}

\section{Typical House}

\$2500 Package. In Table 12, the specific measures to be taken in the typical house in the West are listed, along with their costs and predicted savings. Overall, the total fuel bill would be reduced by 14.3 percent, consumption of site Btus would fall by 16.9 percent, 14.8 percent fewer Btus would be used at the generation source, and $\mathrm{CO}_{2}$ emissions would decline by 16.6 percent. The actual cost of the full package of weatherization measures would be only $\$ 1499$. The individual measures expected to yield the greatest savings of site Btus are air sealing and resetting the temperature setting of the water heater from medium-high to medium-low. Replacing the old refrigerator with a new, energy-efficient one and installing compact fluorescent bulbs would result in substantial savings in fuel bills and source Btus. The cost of this weatherization package is especially low because the cost-effective actions to be taken in this house are relatively inexpensive and do not include the installation of attic, wall, or floor insulation.

Expanded Package. No additional measures were found to be cost-effective for the typical house in this city. ${ }^{20}$

\section{High-Energy-Use House}

$\$ 2500$ Package. Table 13 shows the savings achieved by this package of measures and the associated costs. Fuel bill savings would equal 20.6 percent and source Btu savings would be 24.5 percent. For site Btu savings and $\mathrm{CO}_{2}$ reductions, savings would be 21.5 percent and 24.1 percent, respectively. The total cost of the entire package of measures would be $\$ 2311$. The energy efficiency improvements expected to result in the highest site Btu savings are air sealing, resetting the water heater temperature from medium-high to medium-low, and installing attic insulation. Refrigerator replacement would result in the highest fuel bill and source Btu savings of any measure.

Expanded Package. Once again, no additional measures were found to be cost-effective.

\footnotetext{
${ }^{20}$ However, houses in this area with electric water heaters would be good candidates for water heater replacement and the installation of water heater timers.
} 
Table 12. Weatherization measures, costs, and savings for typical house in West

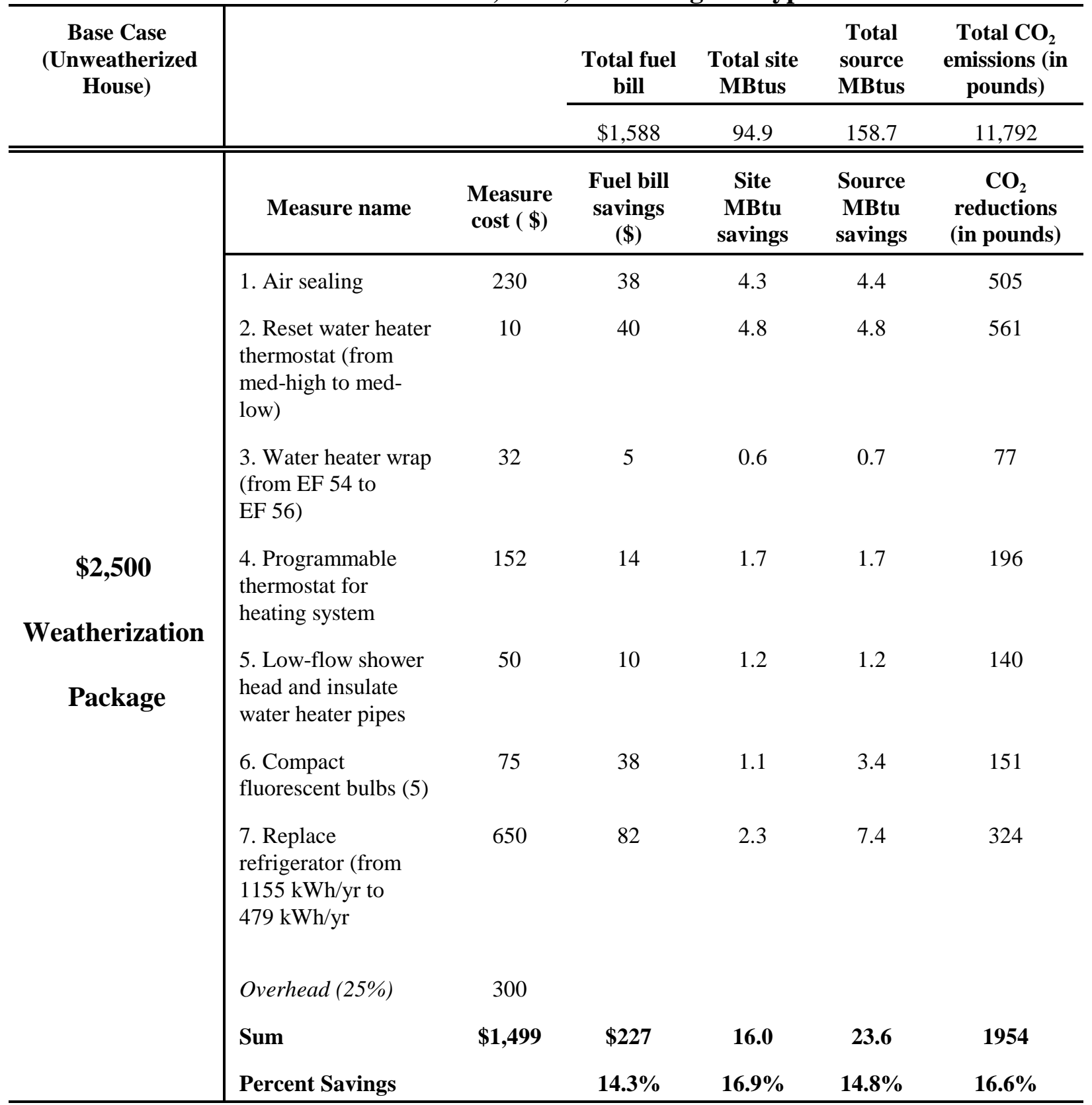


Table 13. Weatherization measures, costs, and savings for high-energy-use house in West

\begin{tabular}{|c|c|c|c|c|c|c|}
\hline \multirow{2}{*}{$\begin{array}{c}\text { Base Case } \\
\text { (Unweatherized } \\
\text { House) }\end{array}$} & & & $\begin{array}{c}\text { Total fuel } \\
\text { bill }\end{array}$ & $\begin{array}{c}\text { Total site } \\
\text { MBtus }\end{array}$ & $\begin{array}{l}\text { Total } \\
\text { source } \\
\text { MBtus }\end{array}$ & $\begin{array}{l}\text { Total } \mathrm{CO}_{2} \\
\text { emissions (in } \\
\text { pounds) }\end{array}$ \\
\hline & & & $\$ 1,784$ & 117.3 & 181.2 & 14,408 \\
\hline \multirow{12}{*}{ Weatherization } & Measure name & $\begin{array}{l}\text { Measure } \\
\text { cost (\$) }\end{array}$ & $\begin{array}{l}\text { Fuel bill } \\
\text { savings } \\
\text { (\$) }\end{array}$ & $\begin{array}{c}\text { Site } \\
\text { MBtu } \\
\text { savings }\end{array}$ & $\begin{array}{l}\text { Source } \\
\text { MBtu } \\
\text { savings }\end{array}$ & $\begin{array}{l}\mathrm{CO}_{2} \\
\text { reductions } \\
\text { (in pounds) }\end{array}$ \\
\hline & 1. Air sealing & 300 & 76 & 9.1 & 9.1 & 1065 \\
\hline & $\begin{array}{l}\text { 2. Reset water heater } \\
\text { thermostat (from } \\
\text { med-high to med- } \\
\text { low) }\end{array}$ & 10 & 43 & 5.1 & 5.1 & 596 \\
\hline & $\begin{array}{l}\text { 3. Water heater wrap } \\
\text { (from EF } 50 \text { to } \\
\text { EF 55) }\end{array}$ & 32 & 16 & 1.9 & 1.9 & 217 \\
\hline & $\begin{array}{l}\text { 4. Attic insulation } \\
\text { (from R6 to R25) }\end{array}$ & 580 & 41 & 4.6 & 4.8 & 548 \\
\hline & $\begin{array}{l}\text { 5. Programmable } \\
\text { thermostat for } \\
\text { heating system }\end{array}$ & 152 & 19 & 2.3 & 2.3 & 266 \\
\hline & $\begin{array}{l}6 \text { Low-flow shower } \\
\text { head and insulate } \\
\text { water heater pipes }\end{array}$ & 50 & 10 & 1.2 & 1.2 & 140 \\
\hline & $\begin{array}{l}\text { 7. Compact } \\
\text { fluorescent bulbs }(5)\end{array}$ & 75 & 38 & 1.1 & 3.4 & 151 \\
\hline & $\begin{array}{l}8 . \text { Replace } \\
\text { refrigerator (from } \\
1500 \mathrm{kWh} / \mathrm{yr} \text {. to } \\
479 \mathrm{kWh} / \mathrm{yr} \text {.) }\end{array}$ & 650 & 125 & 3.5 & 11.1 & 490 \\
\hline & Overhead (25\%) & 462 & & & & \\
\hline & Sum & $\$ 2,311$ & $\$ 368$ & 28.8 & 38.9 & 3473 \\
\hline & percent Savings & & $20.6 \%$ & $24.5 \%$ & $21.5 \%$ & $24.1 \%$ \\
\hline
\end{tabular}





\section{CONCLUSIONS}

Traditionally, the Weatherization Assistance Program has installed measures designed to reduce the energy used for heating and domestic hot water, and the evaluations of program outcomes have focused on reductions in use of the primary heating fuel. In contrast, this study examines the prospects of achieving 30 percent energy use calculated on a whole house basis, an outcome which is made more likely by the addition of electric baseload reduction measures to the menu of energy-efficiency improvements available to the new Weatherization Plus program. The weatherization measures selected for the sample houses examined in this study and the frequency with which they were chosen are illustrated in Figure 7. Many measures that have been part of the Weatherization Assistance Program for years - such as air sealing, low-flow shower heads, attic and wall insulation, water heater wrap and thermostat reset, and programmable thermostats - show up repeatedly in this study as well.

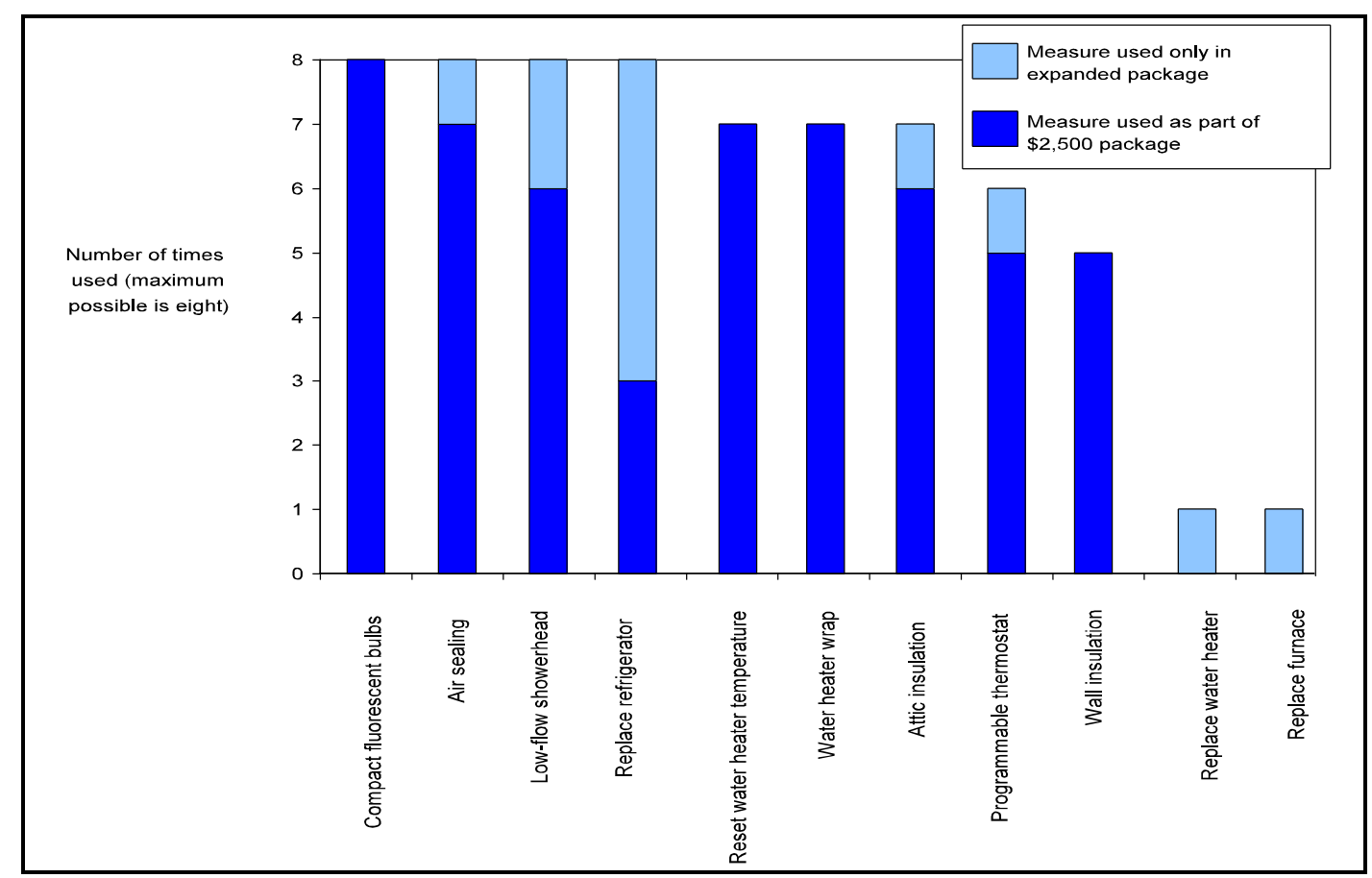

Figure 7. Weatherization measures used in sample house.

Two baseload reduction measures - compact fluorescent bulbs and refrigerator replacement - were chosen for every house in this study. However, because of the cost associated with replacing an old refrigerator with a new energy-efficient unit, this measure was not part of the package of measures installed for the first $\$ 2500$ in more than half the cases. Water heater replacement is a baseload measure suggested as part of the expanded package of 
measures for one of the houses examined. In addition, water heater replacement and substitution of an energy-efficient clothes washer for an older model were found to be nearly cost-effective in the South, where the water heating fuel is electricity. In the future, any increase in fuel prices, decrease in product costs, or technological improvements to appliance efficiency could make these measures more widely cost-effective and could also add other measures (e.g., energyefficient dishwashers) to the list of appropriate options.

Electric baseload measures often produce the greatest impact per dollar invested in the energy bill of the low-income household even if the site Btu savings are more modest. This is because of the high cost of electricity per site Btu relative to other fuels.

\section{THE PROSPECT OF ACHIEVING 30 PERCENT SAVINGS}

Based on the previous discussion, certain conclusions can be drawn about the prospects for achieving savings levels in the 30 percent range through the Weatherization Assistance Program. First, greater savings are achievable in houses with high pre-weatherization energy consumption than in typical dwellings, in all locations. Also, for a given house in a particular area, higher savings can be realized through installation of an expanded set of weatherization measures than from a $\$ 2500$ package in those cases where additional measures are costeffective. The potential for savings in colder climates, where a very large proportion of the total energy budget is used for home heating, is higher than warmer areas, where the bulk of household energy is used for baseload functions. However, houses with exceptionally high energy consumption for producing hot water - like the sample houses in the West - have substantial savings opportunities through measures aimed at cutting the amount of energy used for that function. In multi-fuel houses where gas savings exceed electricity savings, as is typically the case when gas is the home-heating fuel, site Btu savings as a percentage of preweatherization consumption will be greater than for any other unit of measurement, as long as the per-Btu price and $\mathrm{CO}_{2}$ emissions for electricity remain higher than for gas.

A substantial portion of the housing stock in the colder climate regions has the potential for site Btu savings of 30 percent or more given an expanded package of Weatherization Plus measures. This study found that whole-house energy savings in excess of 30 percent are possible in the high-energy-use houses ${ }^{21}$ in the Northeast and Midwest in response to an expanded package of measures costing about $\$ 5600$ and $\$ 7175$, respectively. And with a substantially less expensive package (foregoing water heater and refrigerator replacement in the Northeast and furnace replacement in the Midwest), on-site energy savings of roughly 30 percent (31.7 percent in the Northeast and 28.6 percent in the Midwest) are still achievable. ${ }^{22}$ For the

\footnotetext{
${ }^{21}$ As noted in Chapter 2, high-energy-use houses represent those dwellings that fall in the top quartile (i.e., the upper 25 percent) in terms of their pre-weatherization energy consumption.

${ }^{22}$ These scaled-back packages would cost $\$ 4270$ for the house in the Northeast and $\$ 4050$ for the Midwestern home.
} 
Northeastern high-energy-use house, savings of approximately 19 to 25 percent (depending on the unit of measurement used) can be realized by installing a well-designed $\$ 2500$ package of measures. In the Midwest, the high-energy-use house yields savings of between 22 and 27 percent (depending on the measurement) from a \$2500 package. And the high-energy-use house in the West responds to a package of weatherization measures costing just over $\$ 2300$ with savings of nearly 25 percent in terms of site Btus and $\mathrm{CO}_{2}$ reductions.

Weatherization measures resulting in relatively high savings in most of the houses studied are air sealing, attic and wall insulation, refrigerator replacement, water heater reset, and programmable thermostats. Refrigerator replacement, which is a baseload measure that reduces electricity consumption, excels in terms of fuel bill savings, $\mathrm{CO}_{2}$ reductions, and cutting the use of source Btus. The other measures, in contrast, tend to do best at reducing on-site energy consumption. Measures aimed at reducing heat loss through the building envelope (i.e., air sealing and insulation) achieve the highest levels of savings in cold climates, while baseload reduction measures (including water heater measures) have a proportionally greater effect in milder areas where the heating load is substantially lower.

\section{COMPARISON AMONG SAVINGS DEFINITIONS}

For any given house that uses more than a single fuel type, the percentage savings achieved by installing a particular set of weatherization measures will vary depending on the unit of measurement that is used. This is illustrated in Figure 8 by the substantial variation in the height of the different bars for the Northeast, Midwest, and West. The only region where

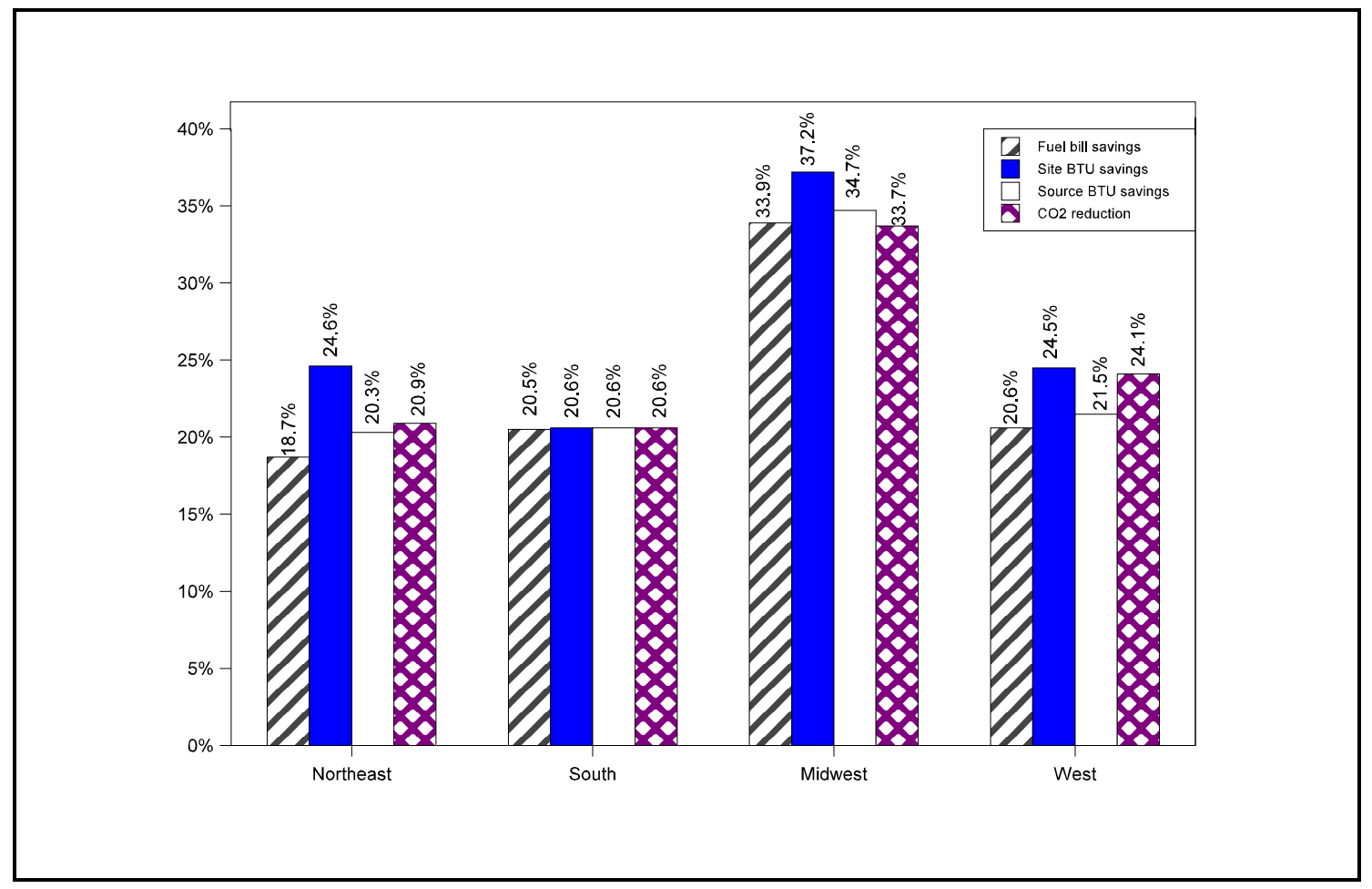

Figure 8. Comparison of savings according to different definitions: $\$ 2500$ package of measures in high-energy houses. 
savings are essentially the same according to all units of measurement is the South, where the sample house utilizes only a single fuel, electricity. Everywhere else, the percentage savings for site Btus are greater than for all other measurements. In the West, the percentage saved is almost as great for $\mathrm{CO}_{2}$ emissions as for site Btus, but this is not the case in the other regions. In the Northeast and West, fuel bill savings are lower than for any other unit of measurement. All of these observations can be explained by examining four factors: fuel mix, the magnitude of savings for each fuel used, relative fuel prices, and the amount of $\mathrm{CO}_{2}$ emissions associated with each energy source.

While this study focuses on whole-house energy use by all fuels, it is possible to look at each household fuel separately to see how the consumption of each is affected by the weatherization measures taken. In all of the houses studied here where more than one fuel is used, gas is used for home heating and gas savings as a percentage of pre-weatherization gas use greatly exceed electricity savings as a percentage of pre-weatherization electricity use. Wherever gas savings outstrip electricity savings in this manner, site Btu savings are greater (as a percentage of pre-weatherization consumption) than source Btu savings. The more gas savings exceed electricity savings, the more site Btu savings surpass source Btu savings. Such differences in savings are greatest where a house uses roughly equal amounts of gas and electricity and are least where one source of energy strongly dominates the fuel mix. ${ }^{23}$

In all of the cities studied, the price of electricity (per site Btu) greatly exceeds the price of gas. ${ }^{24}$ Where gas savings exceed electricity savings, as is generally the case where gas is the home-heating fuel, site Btu savings are greater (relative to pre-weatherization consumption) than fuel bill savings. This difference is amplified as electricity prices go up relative to gas prices. However, as gas prices increase, the gap between site Btu savings and fuel price savings gets smaller.

In each of the cities examined in this study, $\mathrm{CO}_{2}$ emissions per site Btu are greater for electricity than for gas, but the ratio between them varies widely from place to place. ${ }^{25}$ In the Western city, the emissions for each Btu of electricity consumed in the home are 1.2 times greater than for gas consumption. In contrast, the emissions per Btu of electricity consumed in the Midwest are more than four times greater than the emissions per Btu of gas. Where gas

\footnotetext{
${ }^{23}$ Where both gas and electricity were used, the consumption of the former substantially outweighed the latter. The fuel mixes (in terms of site Btus) ranged from 31 percent electricity and 69 percent gas for the typical house in the West to 8 percent electricity and 92 percent gas for the Midwest's high-energy-use house.

${ }^{24}$ Where gas was used, the prices per site MBtu were $\$ 6.39$ in the Midwest, $\$ 8.00$ in the Northeast, and $\$ 8.42$ in the West. In contrast, one site MBtu of electricity cost \$18.46 in the South, \$25.99 in the Midwest, \$35.16 in the Northeast, and $\$ 35.72$ in the West.

${ }^{25} \mathrm{CO}_{2}$ emissions from gas consumption tend to be the same in all parts of the country (117 pounds per $\mathrm{MBtu}$ ). However, emissions from electricity generation vary substantially from place to place depending on the fuel used at the power plant. Generating one MBtu of electricity produced 141 pounds of $\mathrm{CO}_{2}$ in the West, 331 pounds in the Northeast, 494 pounds in the South, and 501 pounds in the Midwest.
} 
savings exceed electricity savings, site Btu savings are greater (relative to pre-weatherization consumption) than the reduction in $\mathrm{CO}_{2}$ emissions. The difference between site Btu savings and the reduction in $\mathrm{CO}_{2}$ emissions gets greater as electricity emissions go up relative to gas emissions. Conversely, in those cases where there is relatively little difference in the emissions associated with gas and electricity (as in the Western city studied), the difference between site Btu savings and emissions reductions is likewise small.

\section{COMPARISON WITHIN REGIONS}

It is instructive to look at the houses studied within a single region to see how the savings realized by the typical house compare to those in the high-energy-use house and how the savings achieved by the $\$ 2500$ and expanded packages compare to each other.

This analysis confirms previous studies which conclude that savings follow consumption. At each of the four sites, regardless of the unit of measurement used (i.e., fuel bill savings, site Btu savings, source Btu savings, or $\mathrm{CO}_{2}$ reductions), the high-energy-use house realizes a higher percentage of savings than does the typical house given comparable levels of investment. The amount by which savings for the high-energy-use house exceed savings for the typical house vary from a low of about 5 percent for all units of measurement in the Southern house to a high of about 45 percent in the West. This comparison is only possible for the $\$ 2500$ package of measures, because the typical houses in two of the regions do not have expanded packages of cost-effective measures.

Expanded packages of weatherization measures were found to be cost-effective for the typical house in two of the four regions (Northeast and Midwest) and for the high-energy-use house in three regions (Northeast, South, and Midwest). Not surprisingly, the percentage of savings achieved from installation of the expanded package of weatherization measures is greater than from the $\$ 2500$ package. This relationship holds at all sites where an expanded package is cost-effective and for all units of measurement.

\section{COMPARISON AMONG REGIONS}

Table 14 shows how savings compare among the four regions for the high-energy-use houses. For the $\$ 2500$ package of weatherization measures, the highest savings according to all units of measurement except for $\mathrm{CO}_{2}$ reductions are found in the Midwest. The high-energy-use house in the West has the greatest $\mathrm{CO}_{2}$ reductions and is fairly close behind the Midwest in terms of the other units of measurement. Savings in the Northeast are relatively close to those in the Midwest and West, especially in terms of site Btus, while the high-energy-use house in the South has the lowest savings in terms of all four units of measurement. For the expanded package of measures, the high-energy-use house in the Midwest once again has the largest savings for all units of measurement, followed fairly closely by the Northeastern house. Again, savings are lowest in the South. 
Table 14. Comparison of savings and costs among census regions: high-energy-use house

\begin{tabular}{lllll}
\hline & Northeast & South & Midwest & West \\
\hline \$2500 Package & & & & \\
Fuel bill savings & $18.7 \%$ & $15.9 \%$ & $22.7 \%$ & $20.6 \%$ \\
Site Btu savings & $24.6 \%$ & $15.9 \%$ & $26.6 \%$ & $24.5 \%$ \\
Source Btu savings & $20.3 \%$ & $15.9 \%$ & $23.7 \%$ & $21.5 \%$ \\
$\mathrm{CO}_{2}$ reductions & $20.9 \%$ & $15.9 \%$ & $22.5 \%$ & $24.1 \%$ \\
Weatherization costs & $\$ 2,732$ & $\$ 2,725$ & $\$ 2,638$ & $\$ 2,311$ \\
Expanded Package & & & & \\
Fuel bill savings & $29.7 \%$ & $20.5 \%$ & $33.9 \%$ & N/A \\
Site Btu savings & $34.4 \%$ & $20.6 \%$ & $37.2 \%$ & N/A \\
Source Btu savings & $31.0 \%$ & $20.6 \%$ & $34.7 \%$ & N/A \\
$\mathrm{CO}_{2}$ reductions & $31.4 \%$ & $20.6 \%$ & $33.7 \%$ & N/A \\
Weatherization costs & $\$ 5,603$ & $\$ 3,500$ & $\$ 7,175$ & N/A \\
\hline
\end{tabular}

Savings are lower in the typical dwellings, with savings from the $\$ 2500$ package of measures being greatest in the Midwest for all four units of measurement. The next highest levels of savings are found in the Northeast. Savings amounts for typical houses in the South and West are fairly close to each other, with the South leading slightly for fuel bill and source Btu savings and the West being higher for site Btu savings and $\mathrm{CO}_{2}$ reductions. The only typical houses that have a cost-effective expanded package of measures are in the Northeast and Midwest and, once again, the Midwest has higher savings levels for all four units of measurement.

Figure 9 shows the percentage of total on-site pre-weatherization energy that is used for heating and for hot water in the high-energy-use house for each of the four regions. The highenergy-use house in the Midwest uses the highest proportion of its total energy for heating, followed by the dwelling in the Northeast. The houses in the South and West come in third and fourth, respectively, in terms of energy used for heating, lagging substantially behind the houses in the colder climates. In contrast, the high-energy-use house in the West uses a much larger proportion of its energy budget to produce hot water than do the dwellings in any of the other regions. Because the packages of weatherization measures studied here include a number of highly-effective items aimed at reducing heat loss through the building envelope (e.g., air sealing, attic and wall insulation), it stands to reason that houses in colder climates would experience higher overall energy savings than dwellings in milder climates because they have greater heating loads and, therefore, greater opportunities for energy savings. 


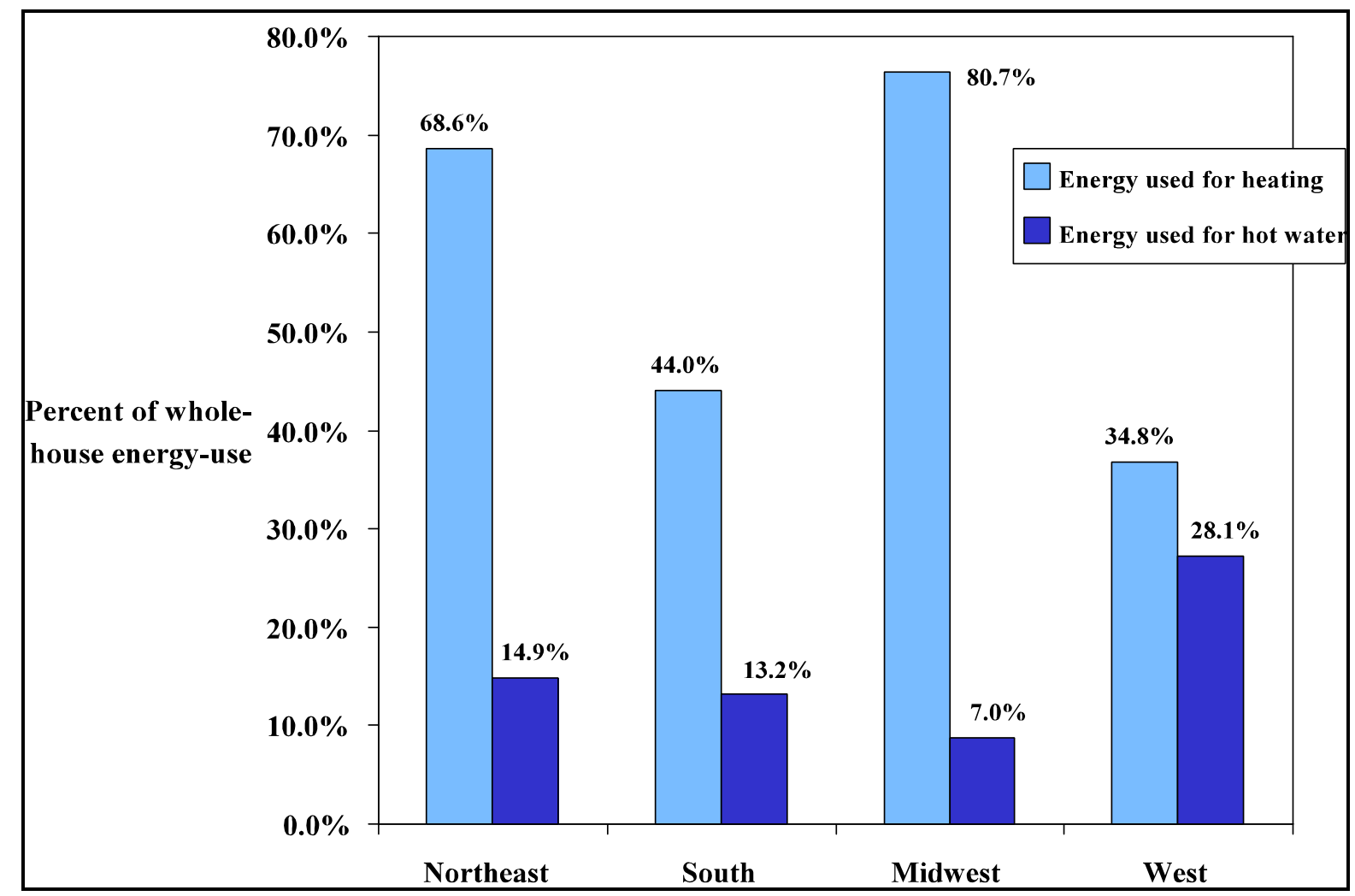

Figure 9. Pre-weatherization energy use for heating and hot water as percent of whole-house on-site energy use: high-energy-use house.

However, the house in the Western region achieves greater savings than climate alone would indicate because of the relatively large amount of energy it uses for hot water. Because of that, measures aimed at reducing the energy used for heating water (such as resetting water heater temperature and water heater wrap) have a much larger effect on the high-energy-use dwelling in the West than in the other regions.

In addition to showing comparative savings, Table 14 also shows the amount of money spent to weatherize the high-energy-use houses in the four census regions. An examination of the numbers shows that additional expenditures within a given area (i.e., going from the $\$ 2500$ package to the expanded package) yield a substantial increase in savings. However, when comparing one region to another, the amount of money spent does not do a very good job of explaining the differences in savings that are achieved. While approximately the same amount is spent on the $\$ 2500$ package in the Midwest, Northeast, and South, the savings in the first two regions are markedly higher than in the last one. And the savings in the West are higher than in the Northeast and South, ${ }^{26}$ despite the fact that the West spends about 15 percent less on its $\$ 2500$ package. the Northeast.

${ }^{26}$ The only exception is for site Btu savings, where the amount saved in the West is marginally lower than in 
There appear to be several explanations for these variations in addition to the obvious differences in heating loads. Household size clearly impacts on appliance and hot water usage, which are coincidental to the regional variations in housing stock. The level of existing insulation, which correlates with housing age, is another factor, with the houses in the West and South being newer (thereby tending to have more insulation) than those in the frost-belt states. The relatively low savings in the South also reflects a scarcity of highly effective measures to reduce energy consumption. This is a subject that calls for more intensive analysis and research.

\section{FUTURE DIRECTIONS}

The information presented in this report shows that there is a real potential for the Weatherization Assistance Program to achieve whole-house savings in the 30 percent range for a portion of the low-income houses that it serves. In addition, savings that fall below that threshold but are still substantial can be realized in many other houses. In general, savings will tend to be higher in colder areas, but the addition of baseload reduction measures to the Weatherization Program increases the opportunity to realize substantial savings throughout the country. Future increases in energy prices, decreases in product costs, and improved appliance efficiencies could increase the cost-effectiveness of several different baseload measures. In addition, new technologies and weatherization techniques, such as heat pump water heaters and advanced duct sealing, might have the potential for achieving higher savings in both typical and high-energy-use houses. The potential savings associated with these new products and circumstances could be explored in future studies.

This study clearly indicates that targeting houses with the greatest pre-weatherization energy consumption and installing an expanded package of weatherization measures in those dwellings will maximize savings. An important area that requires further investigation is the ability of the Weatherization Assistance Program to target high-energy-use households. Achieving a 30 percent savings rate will require identification of the segment of the housing stock at the local level that has high-energy-use characteristics. Assuming these households can be identified, it will require major policy judgments to determine the degree to which these houses deserve priority treatment under the Weatherization Assistance Program and in what proportion they should be served. 


\section{REFERENCES}

Berry, L.G., 1997. State-Level Evaluations of the Weatherization Assistance Program in 19901996: A Metaevaluation That Estimates National Savings, ORNL/CON-435, Oak Ridge National Laboratory, Oak Ridge, Tennessee, January.

Berry, L.G., and M.A. Brown, 1994. Patterns of Impact in the Weatherization Assistance Program: A Closer Look, ORNL/CON-331, Oak Ridge National Laboratory, Oak Ridge, Tennessee, June.

Blasnik, M., 1998. Impact Evaluation of Ohio's Home Weatherization Assistance Program 1994 Program Year, Final Draft \#3. Proctor Engineering Group. A Report to the Ohio Department of Development, Office of Energy Efficiency, May 28.

Brown, M.A., L. Berry, R. Balzer, and E. Faby, 1993. National Impacts of the Weatherization Assistance Program in Single-Family and Small Multifamily Dwellings, ORNL/CON326, Oak Ridge National Laboratory, Oak Ridge, Tennessee, May.

Brown, M., and P. Mihlmester, 1995. "Actual vs. Anticipated Savings from DSM Programs: An Assessment of the California Experience," Proceedings of the 1995 International Energy Program Evaluation Conference, Energy Program Evaluation: Uses, Methods, and Results, Chicago, Illinois, pp. 295-301.

Gas Appliance Manufacturers Association (GAMA), 1990. October 1990 Consumers' Directory of Certified Efficiency Ratings for Residential Heating and Water Heating Equipment, Arlington, Virginia.

Gettings, M.B., L.G. Berry, M.A. Beyer, and J.B. Maxwell, 1998. Validation of the National Energy Audit (NEAT) with Data from a Gas Utility Low-Income Residential Weatherization Program in New York State, ORNL/CON-457, Oak Ridge National Laboratory, Oak Ridge, Tennessee.

Heim, R.R. Jr., C. Garvin, and L. Nicodemus, 1993. State, Regional, and National Monthly and Seasonal Heating Degree Days Weighted by Population (1990 Census) July 1931-June 1992, National Oceanic and Atmospheric Administration, Asheville, NC, July.

Lawrence Berkeley National Laboratory, 1999. About the Home Energy Saver. Http://HomeEnergySaver.lbl.gov/hes/about.html.

Martin, M.A., and M.B. Gettings, 1998. Review of Water, Lighting, and Cooling Energy Efficiency Measures for Low-Income Homes Located in Warm Climates, ORNL/CON437, Oak Ridge National Laboratory, Oak Ridge, Tennessee, February. 
Nadel, S., and K. Keating, 1991. "Engineering Estimates vs. Impact Evaluation Results: How Do They Compare and Why?", Proceedings of the 1991 International Energy Program Evaluation Conference, Energy Program Evaluation: Uses, Methods, and Results, Chicago, Illinois, pp. 24-33.

Nadel, S., L. Rainer, M. Shepard, M. Suozzo, and J. Thorne, 1998. Emerging Energy-Saving Technologies and Practices in the Buildings Sector, ACEEE, Washington, DC.

Peterson, S. R., 1993. DISCOUNT - A Program for Discounting Computations in Life-Cycle Cost Analyses, User's Guide and Reference Manual, U.S. Department of Commerce, Gaithersburg, Maryland.

Reed, J.H., N.P. Hall, A. Oh, P. Hoover, and J. Oh, 1997. An Impact Evaluation of Vermont's Weatherization Assistance Program, A Report Prepared for Vermont State Office of Economic Opportunity Weatherization Assistance Program, TecMRKT Works, Arlington, VA, December.

RLW Analytics, Inc., 1998. Evaluation of the Energy Saving Partners Program, Draft report. Prepared for Public Service Company of Colorado, Clark Lake, Michigan, April 15.

Rutkowski, A., 1986. Residential Load Calculation, Manual J, Air Conditioning Contractors of America, Washington, DC.

Schweitzer, M., and L. Berry, 1999. Metaevaluation of National Weatherization Assistance Program Based on State Studies, 1996-1998, ORNL/CON-467, Oak Ridge National Laboratory, Oak Ridge, Tennessee, May.

Schweitzer, M., and L. Berry, 2000. Evaluation of the Washington State Weatherization Assistance Program, Draft, ORNL/CON-478, Oak Ridge National Laboratory, Oak Ridge, Tennessee, June.

Ternes, M.P., P.S. Hu, L.S. Williams, and P. Goewey, 1991. The National Fuel End-Use Efficiency Field Test: Energy Savings and Performance of an Improved Energy Conservation Measure Selection Technique, ORNL/CON 303, Oak Ridge National Laboratory, Oak Ridge, Tennessee, March.

U.S. Bureau of the Census, 1999. State Population Estimates: Annual Time Series, July 1, 1990 to July 1, 1999, Population Estimates Program, Population Division, U.S. Census Bureau, Washington, DC.

U.S. Energy Information Administration, 1995. Household Energy Consumption and Expenditures 1993, DOE/EIA-0321(93), U.S. Department of Energy, Washington, DC, October. 
U.S. Energy Information Administration, 1999. A Look at Residential Energy Consumption in 1997, DOE/EIA-0632 (97), U.S. Department of Energy, Washington, DC, November.

U.S. Energy Information Administration, 2001. Annual Energy Outlook 2002 With Projections to 2020, DOE/EIA-0383 (2002), U.S. Department of Energy, Washington, DC, December.

U.S. Energy Information Administration, 2002. Short-Term Energy Outlook-March 2002, www.eia.doe.gov, U.S. Department of Energy, Washington, DC, March 6.

Wenzel, T.P., J.G. Koomey, G.J. Rosenquist, M. Sanchez, J.W. Hanford, 1997. Energy Data Sourcebook for the U.S. Residential Sector, LBL-4027/UC-1600, Lawrence Berkeley National Laboratory, Berkeley, CA, September. 

ORNL/CON-479

\section{INTERNAL DISTRIBUTION}

$\begin{array}{ll}\text { 1. } & \text { L. G. Berry } \\ \text { 2. } & \text { M. A. Brown } \\ \text { 3. } & \text { W. G. Craddick } \\ \text { 4. } & \text { T. R. Curlee } \\ \text { 5-22. } & \text { M. T. Eady } \\ \text { 23. } & \text { J. F. Eisenberg } \\ \text { 24. } & \text { E. C. Fox } \\ \text { 25. } & \text { M. B. Gettings } \\ \text { 26. } & \text { S. G. Hildebrand } \\ \text { 27. } & \text { M. Schweitzer } \\ \text { 28. } & \text { R. B. Shelton } \\ \text { 29. } & \text { B. E. Tonn } \\ \text { 30-32. ESD Library } \\ \text { 33. } & \text { ORNL Central Research Library } \\ \text { 34. } & \text { ORNL Laboratory Records-RC }\end{array}$

\section{EXTERNAL DISTRIBUTION}

35. Mr. Kevin Abbott, Community Action Agency of Northeast Alabama, P.O. Box 1487, Rainsville, AL 35986.

36. Mr. Robert Adams, National Association for State Community Service Programs, $400 \mathrm{~N}$. Capitol Street, NW, Suite 395, Washington, DC 20001.

37. Mr. Eric Beaton, U.S. DOE Boston Regional Office, Weatherization Program Manager, JFK Federal Building, Room 675, Boston, MA 02203-0002.

38. Ms. Beth M. Cahall, U.S. DOE Philadelphia Regional Office, Weatherization Program Manager, 1880 John F. Kennedy Boulevard, Suite 501, Philadelphia, PA 19103-7483.

39. Mr. James Childs, U.S. DOE, EE-42, Room 5E-066, Office of Technology Assistance, 1000 Independence Avenue, SW, Washington, DC 20585.

40. Mr. Patrick Connolly, New York State Division of Housing and Community Renewal, 38-40 State Street, 4 South, Albany, NY 12207.

41. Mr. Wayne Curtis, Illinois Department of Commerce and Community Affairs, 620 E. Adams Street, $4^{\text {th }}$ Floor CIPS Building, Springfield, IL 62701.

42. Mr. Rob DeSoto, U.S. DOE Golden Regional Office, Weatherization Program Manager, 1617 Cole Boulevard, Golden, CO 80401.

43. Ms. Jean M. Diggs, U.S. DOE, EE-42, Room 5E-080, Office of Technology Assistance, 1000 Independence Avenue, SW, Washington, DC 20585.

44. Mr. Jerome Dion, U.S. DOE, EE-40, Room 5E-052, 1000 Independence Avenue, SW, Washington, DC 20585. 
45. Mr. Denis J. Feck, U.S. DOE, EE-42, Room 5E-098, Office of Technology Assistance, 1000 Independence Avenue, SW, Washington, DC 20585.

46. Ms. Carole Gates, U.S. DOE Seattle Regional Office, Weatherization Program Manager, 800 Fifth Avenue, Suite 3950, Seattle, WA 98104.

47. Mr. Edward Haber, Illinois Department of Commerce and Community Affairs, 620 E. Adams Street, $4^{\text {th }}$ Floor CIPS Building, Springfield, IL 62701.

48. Mr. John Howat, National Consumer Law Center, 77 Summer Street, $10^{\text {th }}$ Floor, Boston, MA 02110-1006.

49. Ms. Val Martinez, Redwood Community Action Agency, 904 G Street, Eureka, CA 95501.

49-58. Ms. Gail N. McKinley, U.S. DOE, EE-42, Room 5E-080, Office of Technology Assistance, 1000 Independence Avenue, SW, Washington, DC 20585.

59. Mr. Jerrold Oppenheim, 57 Middle Street, Gloucester, MA 01930.

60. Mr. Michael Peterson, U.S. DOE Chicago Regional Office, Weatherization Program Manager, One South Wacker Drive, Suite 2380, Chicago, IL 60606.

61. Dr. Meg Power, Economic Opportunity Studies, 444 N. Capitol Street, Suite G-80, Washington, DC 20001.

62. Mr. Gregory M. Reamy, U.S. DOE, EE-42, Room 5E-066, Office of Technology Assistance, 1000 Independence Avenue, SW, Washington, DC 20585.

63. Mr. Jeff Riggert, TecMRKT Works, 165 W. Netherwood, Oregon, WI 53575.

64. Mr. P. Richard Rittelmann, FAIA, Executive Vice President, Burt Hill Kosar Associates, 400 Morgan Center, Butler, PA 16001-5977.

65. Ms. Bernadette Ruffin, U.S. DOE Atlanta Regional Office, Weatherization Program Manager, 730 Peachtree Street, NE, Suite 876, Atlanta, GA 30308.

66. Dr. Lisa A. Skumatz, Skumatz Economic Research Associates, Inc., 762 Eldorado Drive, Superior, CO 80027.

67. Mr. David Terry, NASEO, 1414 Prince Street, Suite 200, Alexandria, VA 22314.

68. Dr. Susan F. Tierney, The Economic Resource Group, Inc., One Mifflin Place, Cambridge, MA 02138. 